
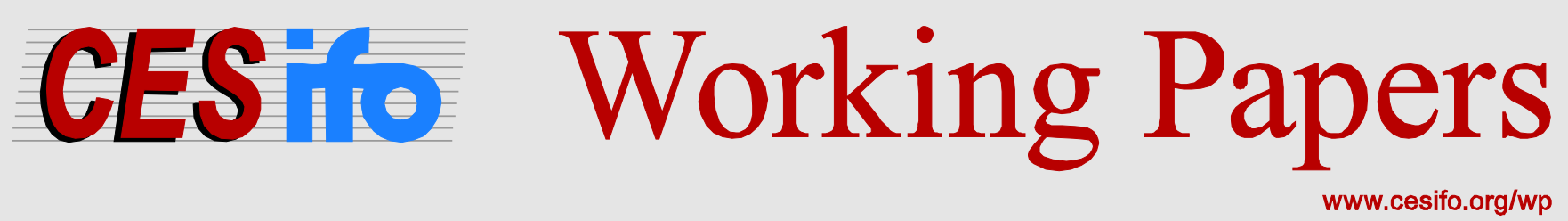

\title{
Do Natural Hazards Cause International Migration?
}

\author{
Jasmin Gröschl \\ Thomas Steinwachs
}

\author{
CESIFO WORKING PAPER NO. 6145 \\ CATEGORY 10: ENERGY AND CliMATE ECONOMICS \\ OCTOBER 2016
}

An electronic version of the paper may be downloaded

- from the SSRN website:

- from the RePEc website:

- from the CESifo website: www.SSRN.com

www.RePEc.org

www.CESifo-group.org/wp 


\title{
Do Natural Hazards Cause International Migration?
}

\begin{abstract}
The estimated amount of people affected by natural hazards stands at a staggering number of about 243 million people per year. While not all of the affected move across borders, international migration potentially provides an adaptation mechanism to natural hazards. The aim of this paper is to assess whether natural hazards induce international migration from a macro perspective. We construct a stylized theoretical gravity model of migration that includes hazards as random shocks. To estimate this model, we deploy exogenous data on geological and meteorological hazards from 1980 to 2010. We combine this data with the World Bank's Global Bilateral Migration Database. Overall, our results suggest little evidence that natural hazards affect medium to long-run international migration. However, considering heterogeneity across income groups, we find that particularly middle-income countries experience significant push and pull effects on migration from natural hazards.
\end{abstract}

JEL-Codes: F220, O150, Q540.

Keywords: natural hazards, international migration, gravity model, heterogeneity across income groups.

\author{
Jasmin Gröschl \\ Ifo Institute - Leibniz Institute for \\ Economic Research \\ at the University of Munich \\ Poschingerstrasse 5 \\ Germany-81679 Munich \\ groeschl@ifo.de
}

\author{
Thomas Steinwachs \\ Ifo Institute - Leibniz Institute for \\ Economic Research \\ at the University of Munich \\ Poschingerstrasse 5 \\ Germany - 81679 Munich \\ steinwachs@ifo.de
}

October 13, 2016

We thank Michel Beine, Ilan Noy, Max Steinhardt, and workshop participants of the CESifo Venice Summer Institute on Climate Change and Migration, the EEA 2016 in Geneva, the ETSG 2016 in Helsinki and the International Economics workshop 2016 in Göttingen for comments and suggestions. 


\section{Introduction}

According to the UN-DESA 2016 report on migration, 244 million international migrants are living in the world in 2015. 157 million of these stem from middle-income countries with their numbers rising more rapidly than those from other income groups. Related to this, the amount of people affected by natural hazards stands at an estimated number of 243 million per year. ${ }^{1}$ The reports by the IPCC (2012), by the World Bank (2012) and the Stern Review (Stern, 2006) particularly accentuate that climate change and natural hazards have become serious issues that are global in their consequences. If global warming progresses, it will become increasingly impossible to sustain livelihoods in some regions so that the numbers of those needing to relocate permanently will continue to increase (Stern, 2006; Marchiori and Schumacher, 2011; IPCC, 2012; Economist, 2012). Historically, the vast bulk of relocation of people caused by hazards has occurred within nations. ${ }^{2}$ Even though not all of the affected move across borders, international migration might provide a potential adaptation mechanism in the presence of natural hazards (McLeman and Smit, 2006; Tacoli, 2009; Barnett and Webber, 2010; Marchiori and Schumacher, 2011).

On these grounds, the impact of increasingly extreme natural hazards on the worldwide relocation of people is one of the major potentially problematic issues that need scrutiny. Knowledge remains limited on the factors at work involving hazards as a cause of international migration. Two channels advocated by Marchiori and Schumacher (2011) may cause permanent relocation as an adaptation mechanism to natural hazards and climate change. First, if amenities at home change or more infectious diseases occur, this may directly lead to higher emigration abroad. Second, crop failure or aridification in rural areas force people to migrate to urban regions, which puts urban wages under pressure and might thus lead to higher international migration. The rural poor in developing economies are most affected by natural hazards. By contrast, they are often liquidity contraint and least able to insure themselves or adopt alternative adaptation strategies. Moreover unfettered migration to the global North is not always possible as industrialized nations get increasingly tough on migrants with stricter immigration policies (Boeri and Brücker, 2005).

The aim of this paper is to assess whether natural hazards induce international mi-

\footnotetext{
${ }^{1}$ This was calculated by Oxfam (2009), "Forecasting the numbers of people affected annually by natural hazards up to 2015". Other studies suggest even higher numbers, finding that 135 million are at risk due to desertification alone (INCCCD, 1994), while 200 million are at jeopardy due to sea-level rise (Myers and Myers, 2002).

${ }^{2}$ In this context, previous research found an effect of hazards in particular on migration from rural to urban areas within national boundaries (Barrios, Bertinelli and Strobl, 2006; Beine and Parsons, 2015).
} 
gration from a macro perspective. We relate to the literature on the determinants of migration $^{3}$, to the general empirical literature on bilateral migration ${ }^{4}$, and to the more specific subcategory on the relation between migration and natural hazards or climate change. Empirical research is often regionally constrained. Naudé (2010) and Drabo and Mbaye (2015) investigate the relation between hazards and international migration from Sub-Saharan Africa or developing countries to OECD economies, respectively. They find that hazards cause outmigration. Other studies look at single extreme disasters to evaluate their impact on migration. Ambrosetti and Petrillo (2016) examine intra-national migration flows after L'Aquila's earthquake of 2009, finding a strong increase of outflows from L'Aquila to other provinces and close regions. Yet another branch of literature focuses only on certain hazard types. Reuveny and Moore (2009), Coniglio and Pesce (2015), and Backhaus, Martinez-Zarzoso and Muris (2015) use a gravity framework to analyze the role of origin country climate anomalies on international migration to OECD countries. Their results suggest that an increase in weather-related hazards in the origin increases outmigration. Beine and Parsons (2015) use a comprehensive data set of global migration for 1960 to 2000. They find little direct effects of climate anomalies or disasters on international migration, but rather on migration from rural to urban areas.

A range of promising approaches to identify the link between hazards and migration exists, but the underlying data used in seeking answers often has its drawbacks ${ }^{5}$, which makes it difficult to generalize results and policy implications. As recapitulated by Mbaye and Zimmermann (2015) in a literature review, effects of environmental hazards on migration range from positive to neutral to negative outcomes. Above all, most of the empirical literature suffers from two major problems. First, they exclude migration towards nonOECD countries, which might induce a large measurement error. According to the Global Bilateral Migration Database, migration to non-OECD countries accounts for $51 \%$ of international migration. Piguet, Pécoud and De Guchteneire (2011) note that hazards are unlikely to affect migration in rich and politically stable economies. Exceptions that also include non-OECD destinations are Beine and Parsons (2015), who find little effect of climate change on migration, and Cattaneo and Peri (2016), who find in a monadic regression that higher temperature increases migration to urban areas and middle-income countries, while poor countries are liquidity constrained. Second, studies have often used information on the incidence of disasters from databases drawn from insurance records

\footnotetext{
${ }^{3}$ Important contributions are Sjaastad (1962); Borjas (1987, 1989); Mincer (1978); Stark (1991).

${ }^{4}$ Studies include Lewer and Van den Berg (2008); Pedersen, Pytlikova and Smith (2008); Letouzé et al. (2009); Ortega and Peri (2009); Mayda (2010); Beine, Docquier and Özden (2011), to name a few.

${ }^{5}$ Empirical economists face a lack of observational data and definitions for migration and hazards.
} 
or news. This introduces severe reporting and endogeneity biases, as both, insurance penetration and damage caused are correlated with development, which in turn affects migration patterns (for a detailed discussion, see Felbermayr and Gröschl, 2014).

In this paper, we construct a stylized theoretical gravity model of migration based on derivations by Anderson (2011) and include hazards as random shocks. To estimate the implications of this model, we deploy a conditional fixed effects Poisson Pseudo Maximum Likelihood approach advocated by Santos Silva and Tenreyro (2006). We offer two contributions beyond recent work: (i) we explicitly estimate the time-variant part of multilateral resistance $(\mathrm{MR})^{6}$ in bilateral migration, thereby allowing hazards in the origin and the destination to vary in impact; and (ii) we deploy updated and extended natural hazard data from Ifo GAME based on exogenous intensity measures, thus we solve the endogeneity and reporting problems of insurance- and news-based disaster data.

Our results suggest little impact of natural hazards on medium to long-run international migration in line with findings by Beine and Parsons (2015). Using the full sample and considering the timing of events combined with migration decisions, we find that a mean hazard event at origin leads to $1.7 \%$ more bilateral migration. The identification of statistically significant effects becomes very noisy if we do not consider timing. Moreover, decomposing hazards by type does not yield a clear pattern. When we distinguish countries by income levels, we do find heterogeneity across groups. Individuals from low-income countries do not migrate internationally if struck by natural hazards. International migration or other adaptation strategies may not be feasible for financially constrained individuals (see also Cattaneo and Peri, 2016). If high-income countries experience hazards, their outmigration declines, possibly due to high insurance penetration rates. These may cause incentives to stay as insured capital is upgraded after a hazard. Middle-income countries show a clear pattern of migration due to hazards - which lead to international migration of $1.4 \%$, while those at potential destinations decrease migration by $11.5 \%$, both evaluated at the mean. Hence, examining the effect of natural hazards on migration using a full sample may lead to aggregation bias.

The remainder of the paper is structured as follows. Section II provides a theoretical gravity model of migration. Section III describes details on the empirical strategy and section IV addresses the data. Section V provides results and a sensitivity analysis. The last section concludes.

\footnotetext{
${ }^{6} \mathrm{MR}$ terms are adapted to the setup from the derivations of Baier and Bergstrand (2009) using a Taylor series expansion.
} 


\section{A Gravity Model of Migration}

To provide a simple theoretical motivation for estimating bilateral migration in a gravity framework, we follow Anderson (2011). The decision to migrate is, in contrast to the decision to export, characterized by the choice over a discrete number of alternative locations on a global scale. The costs of migration are common to all migrants within a particular bilateral link, albeit migration costs may have an idiosyncratic component reflecting individual costs or utility from moving.

Consider a multi-country framework where $i, j=1, \cdots, C$ denote countries, $h=$ $1, \cdots, H$ denotes individuals, and $t$ denotes time. Each individual $h$ has an idiosyncratic component of utility from migrating, $\xi_{i j h, t}$, which is unobservable and independently distributed across individuals with an iid extreme value distribution. In addition, individuals face costs of migration, which are the same for all workers that migrate in a particular migration corridor, $\kappa_{i j, t}=\kappa_{j i, t}{ }^{7}$ Migration costs constitute an iceberg cost factor $\kappa_{i j, t} \geq 1$ and $\kappa_{i i, t}=1$ at time $t$. Migration costs are a function of several factors, comprising timeinvariant costs from the move, such as cultural proximity (common language, common colonizer), or geographic location (distance, common border), and time-variant factors, such as networks (stock of migrants), regional networks (regional trade agreements), immigration policies, political ties between country-pairs, or benevolence of welfare states in receiving countries. In addition, migration costs may depend on unobserved bilateral determinants, such as historical affinity of country-pairs, ethnic or business networks. Moreover, migration costs may also follow a common time trend $t$.

When a natural hazard strikes, it damages and destroys both physical and human capital. It follows that hazards affect the migration decision by reducing the productivity of labor. By this they affect wages and eventually also the movement of population. ${ }^{8} \mathrm{We}$ formally introduce natural hazards as random shocks $\Phi$, where $\Phi \geq 1 .{ }^{9}$ The occurrence

\footnotetext{
${ }^{7}$ Note that migration costs may as well vary by skill levels. Migration costs could be lower for skilled workers and increase with decreasing skill level. Individuals with low skill levels may benefit more from migrating but also face relatively higher migration costs given their lower income and potential liquidity constraints they face in situations where they cannot save or borrow enough to pay the costs of migration. On the other hand, migrant networks may increase with skill and thus lead to lower migration costs for the more highly skilled. This implies selection mechanisms by skill, which we abstract from in this model as we cannot test implications empirically on the basis of our global migration data which does not allow us to distinguish migrants by skill level.

${ }^{8}$ Note that natural hazards could also affect migration costs directly, such that migration costs would increase with natural hazards as, for instance, infrastructure or amenities get destroyed. This would make migration more costly and less likely. We abstain from modeling a direct effect; instead we consider that hazards change multilateral resistance of countries, thus assuming an implicit effect on migration costs.

${ }^{9}$ Random shocks may also incorporate civil or international war, changes in governance from autocracy to democracy or vice versa, etc.
} 
of random shocks and the damage they cause are assumed to be idiosyncratic across locations. Random shocks have a transitive effect on labor productivity as they suddenly shift demand and/or supply structures. Let the wage net of migration costs and net of random shocks to labor productivity in the destination be $w_{j, t} /\left(\kappa_{i j, t} \Phi_{j, t}\right)$, where $w_{j, t}$ denotes the wage in destination $j$ at time $t$, and wage net of the labor productivity shock at home is $w_{i, t} / \Phi_{i, t}$, where $w_{i, t}$ denotes the wage at origin $i$ at time $t$ and $\kappa_{i i, t}=1$. Then, an individual $h$ migrates if the utility from migrating to some destination $j$ at time $t$ is larger than from staying at home, $\left(w_{j, t} /\left(\kappa_{i j, t} \Phi_{j, t}\right)\right) \xi_{i j h, t} \geq w_{i, t} / \Phi_{i, t} \cdot{ }^{10}$

To evaluate migration, suppose expected utility is a logarithmic constant relative risk aversion (CRRA) CES function. ${ }^{11}$ Specifically, the observable component of log-linear utility from migrating is

$$
\ln u_{i j, t}=\ln w_{j, t}-\ln \kappa_{i j, t}-\ln \Phi_{j, t}-\left[\ln w_{i, t}-\ln \Phi_{i, t}\right]^{12}
$$

Note that individual decisions can be aggregated up to a representative individual (McFadden, 1974), as migrants are assumed to be homogeneous except for the random term $\xi_{i j h, t}$. To retrieve a tractable gravity equation, we assume that the aggregated level of the discrete choice probability is equal to migration flows from source $i$ to destination $j$ at time $t$. Aggregate bilateral migration is then given as

$$
M_{i j, t}=P\left(u_{i j, t}\right) N_{i, t}
$$

where the population in the source country takes a decision on migration and, with $\xi_{i j h, t}$ following an iid extreme value distribution, the probability $P\left(u_{i j, t}\right)^{13}$ is given by

$$
P\left(u_{i j, t}\right)=P\left(u_{i j, t}=\max _{\mathrm{k}} u_{i k, t}\right)=\frac{e^{u_{i j, t}}}{\sum_{k} e^{u_{i k, t}}} \quad \text { for } \quad i k \neq i j
$$

\footnotetext{
${ }^{10}$ The average expected gain in utility from not migrating (remaining in $i$ ) is zero for individuals that choose to stay in the origin (Ortega and Peri, 2009). $w_{i, t}$ and $\Phi_{i, t}$ are constant across all destinations.

${ }^{11}$ The CES utility function is given as $u_{i j, t}=\frac{1}{\sigma-1}\left(\frac{w_{j, t} /\left(\kappa_{i j, t} \Phi_{j, t}\right)}{w_{i, t} / \Phi_{i, t}}\right)^{\sigma-1}$, where $\sigma$ is the elasticity of substitution for wages in different locations (also called the coefficient of relative risk aversion).

${ }^{12}$ Utility may also be derived from country characteristics $C$ that denote benefits such as public infrastructure, amenities, the welfare state etc. (compare for instance Beine and Parsons (2015) for a more detailed discussion). We do not specifically model these benefits here as we do not devote particular attention to country specific factors which do not alter the prediction of our random shock variable. The role of these factors for migration will in our empirical section be considered by country dummies (timeinvariant) and also by controls and MR terms (time-varying).

${ }^{13}$ For examples of bilateral migration discrete choice models that build on a multinominal logit function, see Beine, Docquier and Özden (2011), Grogger and Hanson (2011), Gibson and McKenzie (2011) or Beine and Parsons (2015).
} 
Since the $\Phi$ 's and $\kappa$ 's enter the model multiplicatively through their effect on wages, they combine into a shock-cost measure $\theta_{i j, t}$ that represents both migration costs and random shocks from natural hazards or similar factors on labor productivity. ${ }^{14}$ Both migration costs and random shocks to labor productivity operate in combination with given wages to generate the allocation of migrants. The combined shock-cost measure is then given as $\theta_{i j, t}=\kappa_{i j, t} \Phi_{j, t} / \Phi_{i, t}$.

With logarithmic utility, the structure of the migration equation corresponds to

$$
M_{i j, t}=\frac{\left(w_{j, t} / \theta_{i j, t}\right)^{\sigma-1}}{\sum_{k}\left(w_{k, t} / \theta_{i k, t}\right)^{\sigma-1}} N_{i, t}
$$

To derive a tractable gravity equation, define $\Gamma_{i, t} \equiv \sum_{k}\left(w_{k, t} / \theta_{i k, t}\right)^{\sigma-1}$ and specify the aggregated labor market clearing condition as $N_{j, t} \equiv \sum_{i} M_{i j, t}$. The clearing condition is then $N_{j, t}=w_{j, t}^{\sigma-1} \sum_{i}\left(\theta_{i j, t}^{1-\sigma} / \Gamma_{i, t}\right) N_{i, t}$. In equilibrium, wages are

$$
w_{j, t}^{\sigma-1}=\frac{N_{j, t}}{N_{t} \Gamma_{j, t}}
$$

with total world population $N_{t} \equiv \sum_{i} N_{i, t} \equiv \sum_{j} N_{j, t}$ and $\Gamma_{j, t}=\sum_{i} \frac{\theta_{i j, t}^{1-\sigma}}{\Gamma_{i, t}} \frac{N_{i, t}}{N_{t}}$. Substituting for the equilibrium wage in equation (4) using equation (5) yields the tractable gravity specification of migration

$$
M_{i j, t}=\frac{N_{i, t} N_{j, t}}{N_{t}}\left(\frac{\theta_{i j, t}}{\tilde{\Gamma}_{i, t} \tilde{\Gamma}_{j, t}}\right)^{1-\sigma}
$$

with the outward migration friction price index $\tilde{\Gamma}_{i, t}=\left[\sum_{j} \frac{N_{j, t}}{N_{t}}\left(\frac{\theta_{i j, t}}{\tilde{\Gamma}_{j, t}}\right)^{1-\sigma}\right]^{1 / 1-\sigma}$ and the inward migration friction price index of $\tilde{\Gamma}_{j, t}=\left[\sum_{i} \frac{N_{i, t}}{N_{t}}\left(\frac{\theta_{i j, t}}{\tilde{\Gamma}_{i, t}}\right)^{1-\sigma}\right]^{1 / 1-\sigma}$.

To make the impact of random shocks visible in the gravity equation of migration, we decompose $\theta_{i j}$. This gives

$$
M_{i j, t}=\frac{N_{i, t} N_{j, t}}{N_{t}}\left(\frac{\kappa_{i j, t}}{\tilde{\Gamma}_{i, t} \tilde{\Gamma}_{j, t}}\right)^{1-\sigma} \Phi_{i, t}^{\sigma-1} \Phi_{j, t}^{1-\sigma}
$$

\footnotetext{
${ }^{14}$ This useful simplification follows Anderson (2009) and is exploited in what follows. It can be decomposed at any point into its components.
} 
and multilateral resistance terms are $\tilde{\Gamma}_{i, t}=\left[\sum_{j} \frac{N_{j, t}}{N_{t}}\left(\frac{\kappa_{i j, t}}{\tilde{\Gamma}_{j, t}}\right)^{1-\sigma}\left(\frac{\Phi_{j, t}}{\Phi_{i, t}}\right)^{1-\sigma}\right]^{1 / 1-\sigma}$ and $\tilde{\Gamma}_{j, t}=$ $\left[\sum_{i} \frac{N_{i, t}}{N_{t}}\left(\frac{\kappa_{i j, t}}{\tilde{\Gamma}_{i, t}}\right)^{1-\sigma}\left(\frac{\Phi_{j, t}}{\Phi_{i, t}}\right)^{1-\sigma}\right]^{1 / 1-\sigma}$.

The first term of equation (7) denotes bilateral migration in a world without frictions, where migrants are found in equal shares relative to the population in all destinations. The second term denotes the impact of frictions in a world that entails costs to migration. The larger bilateral migration costs $\kappa_{i j, t}$, the lower are migration flows. Albeit, in a world in which migrants choose from a set of alternative destinations, migration also depends on multilateral resistance, which captures worldwide bilateral migration costs. The third term indicates that random shocks to labor productivity in the origin and in the receiving country affect migration. The larger the shock in the origin $\Phi_{i, t}$, the higher are migration flows. The larger the shock in the destination $j$ at time $t$, the lower are migration flows.

\section{Empirical Strategy}

To test the predictions of the previous section regarding the effect of hazards on bilateral migration patterns, we outline a fully fledged gravity model on a panel of bilateral migration and primary hazard data. Estimating an augmented gravity specification, we examine how natural hazard in the origin $\left(\Phi_{i, t}\right)$ and in the destination $\left(\Phi_{j, t}\right)$ affect bilateral migration rates $\left(M_{i j, t} / N_{i i, t}\right)$.

To get an estimable equation on migration rates, we take logs of equation (7) and obtain

$$
\ln \frac{M_{i j, t}}{N_{i i, t}}=(1-\sigma) \ln \kappa_{i j, t}+(\sigma-1) \ln \tilde{\Gamma}_{i, t}+(\sigma-1) \ln \tilde{\Gamma}_{j, t}+(\sigma-1) \ln \Phi_{i, t}+(1-\sigma) \ln \Phi_{j, t}{ }^{15}
$$

As discussed earlier in Section II, migration costs comprise time-invariant and timevariant components. We empirically model our cost function as

$$
\kappa_{i j, t}=g\left(\ln \left(D I S T_{i j}\right), A D J_{i j}, L A N_{i j}, C O L_{i j}, R T A_{i j, t}, \text { MigStock }_{i j, t-1}, \nu_{t}, \nu_{i}, \nu_{j}\right)
$$

which is a function of controls for time-invariant historical or cultural country characteristics, such as bilateral distance $\ln \left(D I S T_{i j}\right)$, adjacency $A D J_{i j}$, common language $L A N_{i j}$, and colonial heritage $C O L_{i j}$. The cost function also comprises time-varying components,

\footnotetext{
${ }^{15}$ Note that $N_{t}$ is constant, $\ln N_{j, t}$ is omitted, and $\ln N_{i, t}$ is transformed to $\ln N_{i i, t}$ (the non-migrant population of $i$ ) to obtain migration rates as the dependent variable rather than migration flows. With using migration rates we follow for instance Mayda (2010); Beine and Parsons (2015).
} 
such as regional trade agreements $R T A_{i j, t}$ that account for the fact that more integrated countries or regions might also experience higher migration flows. ${ }^{16}$ MigStock $_{i j, t-1}$ is the stock of migrants from country $i$ residing in $j$ at time $t-1$, which captures network effects. ${ }^{17} \nu_{t}$ are time specific dummies that account for common trends. $\nu_{i}$ and $\nu_{j}$ are a complete collection of origin and destination country dummies which account for all time-invariant country characteristics. Multilateral resistance (MR) terms have a timeinvariant and a time-variant component. While the time-invariant component of MR is fully captured by origin and destination country fixed effects, the time-variant component of MR is captured by $\tilde{\Gamma}_{i, t}$ and $\tilde{\Gamma}_{j, t}$ in equation (8). ${ }^{18}$ As in the traditional gravity model, price indexes are computable once migration costs $\kappa_{i j, t}$ are constructed econometrically.

Zero bilateral migration flows make up about $65 \%$ of observations. To account for these zero migration flows and to correct for heteroskedastic error terms, we choose a conditional fixed effects (FE) Poisson Pseudo Maximum Likelihood (PPML) approach advocated by Santos Silva and Tenreyro (2006). ${ }^{19}$ Based on equation (8), we estimate a gravity equation of the form

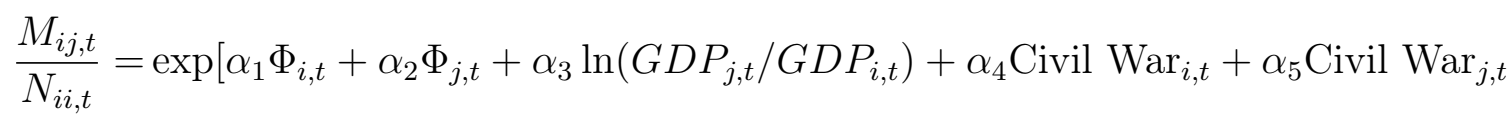

$$
\begin{aligned}
& \left.+\boldsymbol{\alpha}_{6} \kappa_{i j, t}+\boldsymbol{\alpha}_{7} \mathrm{MR}_{\mathbf{i j}, \mathrm{t}}\right]+\varepsilon_{i j, t} .
\end{aligned}
$$

where $\frac{M_{i j, t}}{N_{i i, t}}$ is the decennial bilateral migration rate calculated as the migration flow from $i$ to $j$ at decade $t$ divided by the domestic non-migrant population in country $i . \Phi_{i, t}$ $\left(\Phi_{j, t}\right)$ capture the physical intensity of natural hazards in the origin (destination) in a given decade. These may be included as an index variable or separately for specific types (see data section for more detail). As common in the migration-hazard literature, we include two country specific controls directly that vary over time. $G D P_{j, t} / G D P_{i, t}$ is the ratio of destination to origin decennial average per capita GDP and proxies average wage

\footnotetext{
${ }^{16}$ Our RTA variable incorporates free trade agreements, currency unions and customs unions.

${ }^{17}$ The literature on networks identifies migrant networks to promote bilateral migration flows, trade and capital flows (Rauch and Trindade, 2002; Munshi, 2003; Kugler and Rapoport, 2007; Docquier and Lodigiani, 2010). In particular, Beine, Docquier and Özden (2011) find that migrant networks significantly increase migration flows to OECD countries.

${ }^{18}$ Ideally, the time-variant component of MR is controlled for using time-varying country fixed effects. Since our hazard variables are country-time specific, this approach is unfeasible. The fixed effects would pick up the variation in our variables of interest.

${ }^{19}$ If zeros are prevalent in the data and error terms are heteroscedastic, PPML generates consistent estimates even when the underlying distribution is not strictly Poisson.
} 
differences. Civil $\operatorname{War}_{n, t}$ with $n=i, j$ are count variables of the number of years in which civil wars took place in the source or the receiving country, respectively, within the last 10 years of observation. $\boldsymbol{\kappa}_{\boldsymbol{i j , \boldsymbol { t }}}$ is a vector of migration costs as outlined in equation (9). It includes time constant and time-varying costs including a complete collection of origin and destination country dummies and time specific fixed effects. The constructed MR terms

$\mathbf{M R}_{\mathbf{i j}, \mathbf{t}}=\tilde{\Gamma}_{i, t}, \tilde{\Gamma}_{j, t}$ capture the time-variant component of multilateral resistance (e.g., immigration policies or benevolence of the welfare state). We derive MR indices from a first-order Taylor series expansion of the gravity equation following an approach by Baier and Bergstrand (2009). We approximate MR terms based on distance (MRDIST ${ }_{i j, t}$ ), adjacency $\left(\mathrm{MRADJ}_{i j, t}\right)$, common language $\left(\mathrm{MRLAN}_{i j, t}\right)$, colonial relationship $\left(\mathrm{MRCOL}_{i j, t}\right)$, and RTAs $\left(\right.$ MRRTA $\left._{i j, t}\right)$ which we weight by population over world population (a proxy for a country's relative migrant potential). For details see Appendix A. This econometric approach allows us to control simultaneously for the direct effects of hazards in the source and the destination country and for time-varying country characteristics absorbed in the MR terms. $\varepsilon_{i j, t}$ is an additive error term.

Our model suggests that $\alpha_{1}$ is positive such that hazards in the origin induce migration out of affected countries, while $\alpha_{2}$ is negative indicating that hazards in potential destinations reduce migration. We will now bring this theoretical prediction to the data.

\section{Data}

\section{A. International Migration}

We combine two data sets. The Global Migrant Origin Database (Version 4, 2007) provided by the World Bank reports bilateral migration stocks based primarily on the foreignborn concept in intervals of 10 years from 1960 to 2000 for 226 countries. The data set combines census and population register records to construct decennial matrices corresponding to the last five completed census rounds. Data for 2010 are also provided by the World Bank and updates data by Ratha and Shaw (2007) as described in the Migration and Remittances Factbook 2011. The 2010 data set also uses the foreign-born concept and similar sources and methods as the 1960-2000 data. ${ }^{20}$

To calculate bilateral decennial migration rates, we take the difference between contiguous bilateral migrant stocks to approximate migration flows, which we then divide by the

\footnotetext{
${ }^{20}$ Note that the World Bank data relies on official census data, hence undocumented migrants or refugees are not included. Temporary migration is included only if if the stay extends across a census date. The data does not allow identifying how big the share of temporary migrants is.
} 
non-migrant origin population (following Beine and Parsons, 2015). This is constructed as the country's total population (according to WDI) minus the sum of immigrants in that country. In some cases migration stocks shrink over the observed time period which leads to negative values. As the exact reason of the decrease in migration stocks is not clear, we stay in line with the literature and ignore all negative values by setting them to zero, implicitly assuming that migrant stocks decrease due people's deaths. ${ }^{21}$

In our sample, zero bilateral migration flows make up about $65 \%$ of observations. To account for these zero migration flows and a potentially heteroskedastic error structure, we estimate a FE PPML approach. Still, we lose observations due to missing data for migration rates, control variables and natural hazards, preserving 66,673 observations used in the PPML estimation. These preserved observations spread over all three decades (17,556 observations for 1981-1990, 24,806 for 1991-2000, and 24,311 for 2001-2010) and across 162 countries as listed in Appendix B, Table 7. Hence, we expect sufficient variation in our data. ${ }^{22}$

\section{B. Natural Hazards}

We use natural hazard data from the Ifo GAME database on geological and meteorological events, first introduced by Felbermayr and Gröschl (2014). The database contains physical intensities of earthquakes, volcanic explosions, storms, droughts, floods, and temperature anomalies on a monthly basis from 1979 to 2014 for 232 countries. $^{23}$ The data included in Ifo GAME stem from various primary sources and come in two different types of geocoding requiring different treatment: (a) non-gridded hazards (volcanoes, hurricanes, and earthquakes) are aggregated to the country level by directly mapping the data to all countries within a radial geodesic buffer around the exact hazard geolocation; ${ }^{24}$ (b) gridded data (temperatures, precipitation, SPEI) are aggregated to the country level by

\footnotetext{
${ }^{21}$ The actual reasons for negative differences between subsequent bilateral migrant stocks can be a mixture of mortality, return migration, or migration to a third country. The data does not allow us to disentangle the true drivers of negative stock differences.

${ }^{22}$ The loss of data is commonly known in the literature. For example Beine and Parsons (2015), the paper closest related to ours, have similar numbers of observations spread over four decades from 1960-2000.

${ }^{23}$ An earlier version of the Ifo GAME data base ranging from 1979 to 2010, covering 188 countries, and using slightly different mapping procedures is currently available at http://www.cesifo-group.de/ ifoHome/research/Departments/International-Trade/Ifo_GAME.html.

${ }^{24}$ Not knowing the true spatial extent of natural hazards poses a potential problem. Volcanoes are very local events, but gas plumes can have extensive impact. Also, the true geographic extent of earthquakes and hurricanes is not easy to predict given only their magnitude and location at center. In addition, geological, meteorological and surface characteristics matter. We thus rely on approximations from the literature, as the prediction of the true spatial extent of hazard events lies beyond the scope of this paper.
} 
calculating area-weighted arithmetic means. The exact data sources as well as the respective spatio-temporal aggregation procedures and index choices are described in detail below; descriptive statistics are shown in Figure 2.

Earthquakes. We measure a country's earthquake hazard by its maximum magnitude. To obtain this, physical earthquake magnitudes from the Incorporated Research Institutions for Seismology (IRIS) are mapped to each country within $150 \mathrm{~km}$ of the respective epicenter. We aggregate to the decennial level by collapsing maximum earthquake magnitudes across all months. The resulting earthquake magnitude is distributed between 0 and 10, with a mean of 5.9 and a standard deviation of 1.9 (compare Figure 2).

Volcanic Explosions. A country's volcanic activity is measured by its maximum volcanic explosivity index (VEI). VEI is obtained from the Smithsonian Global Volcanism Program and mapped to each country within $50 \mathrm{~km}$ of the respective volcano's geolocation. We aggregate VEI for each country to the decennial level by collapsing VEI to their maximum across all months. Resulting VEIs are distributed between 0 and 6 , with a mean of around 0.4 and a standard deviation of 1.1 (compare Figure 2).

Storms. In order to measure a country's storm hazard, we use the maximum combined wind speed of a country from two data sources. Hurricane wind speeds in knots at the exact locations and paths of hurricane centers come from the International Best Track Archive for Climate Stewardship (IBTrACS) v03r07, provided by the World Meteorological Organization (WMO) and the US National Oceanic and Atmospheric Administration (NOAA). We map hurricane wind speeds to each country within a $100 \mathrm{~km}$ range of the respective hurricane eye. Wind speeds of winter or summer storms in knots stem from weather station data of the Global Summary of the Day (GSOD) statistics. This reports wind speeds measured at terrestrial weather stations worldwide by the exact geolocation of the respective station. To obtain a decennial measure for each country, we collapse maximum wind speeds across all months. Resulting combined wind speed is distributed between 16 and 165 knots, with a mean of 78.3 and a standard deviation of 29.8 (compare Figure 2).

Temperature. We measure extreme temperature by the absolute mean temperature difference from the long-run monthly mean. Monthly mean land surface air temperatures in degrees Celsius at $0.5^{\circ} \times 0.5^{\circ}$ latitude-longitude grid cell levels come from the Climate Prediction Center of the National Centers for Environmental Prediction. The 
data combine and interpolate data collected from the Global Historical Climatology Network Version 2 (GHCN) and the Climate Anomaly Monitoring System (CAMS). Spatially aggregating grid cell data addresses two caveats. First, coordinates of measuring points are located at grid cell centers which means that (a) small countries may not have any measuring points within their geographic boundaries, and (b) for larger countries, measuring points in border regions may concern only a relatively small aerial fraction. Second, fixed-degree grid cells feature varying metric area along latitudes due to the earth's curvature. Hence, measuring points more remote from the equator affect smaller land area. We apply the following procedure to address both caveats: First, we split each country

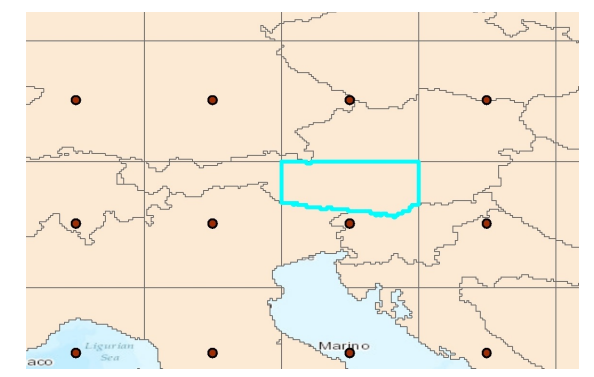

Figure 1: $2.5^{\circ}$ grid cell aggregation example

$i$ into fractions frac by grid cells. Second, we calculate geodesic land area $a$ in $\mathrm{km}^{2}$ for each fraction in a cell. At any point in time $t$, we add values of each measuring point to all fractions within its respective cell, as they constitute the best proxy available in their respective grid cell (compare Figure 1). Finally, we aggregate gridded observations to the country level by calculating a weighted mean using each country's geodesic land area within a grid cell as analytic weights using

$$
\bar{x}^{*^{i, t}}=\frac{\sum_{\text {frac } \in i} a_{\text {frac }}^{i} \cdot x_{f r a c}^{i, t}}{\sum_{\text {frac } \in i} a_{\text {frac }}^{i}}
$$

We then calculate the differences between monthly mean temperatures and the longrun (1979-2014) monthly mean for each country. For our decennial data, we collapse temperature differences across all months. In order to treat heat and cold waves alike, we take the absolute value of the measure (see also Felbermayr and Gröschl, 2014). The absolute temperature difference is distributed between 0 and 1.4 degrees Celsius, with a mean of 0.3 and a standard deviation of 0.2 (compare Figure 2). 
Precipitation. Excessive precipitation, which might exceed percolation and sewage capacities, is captured by the positive maximum precipitation difference from the long-run monthly mean. We obtain monthly mean precipitation in $\mathrm{mm} /$ day at $2.5^{\circ} \times 2.5^{\circ}$ latitudelongitude grid cell level from the National Aeronautics and Space Administration (NASA) Global Monthly Merged Precipitation Analyses of the Global Precipitation Climatology Project (GPCP) Version 2.2, which combines and harmonizes observations from satellites and weather stations (gauges). We aggregate the gridded observations to the country level in the same way as for temperatures (see equation (11)). For each country, we then calculate the differences between monthly mean precipitation and the long-run (1979-2014) monthly mean. For the decennial level, we use maximum precipitation differences across all months. To avoid picking up the effect of potential droughts, we only work with positive maxima. The resulting indicator is distributed between 0.1 and 21.2 , with a mean of 4.2 and a standard deviation of 2.9 (compare Figure 2).

Droughts. To approximate droughts, we deploy the negative mean of the Standardized Precipitation-Evapotranspiration Index (SPEI) computed at a time-scale of 9 months. ${ }^{25}$ We obtain monthly mean precipitation in $\mathrm{mm} /$ day at $0.5^{\circ} \times 0.5^{\circ}$ latitude-longitude grid cell level from the Climatic Research Unit of the University of East Anglia (CRU TS v3.23). While this data set is based on weather stations its longer time-scope and the availability of information on evapotranspiration are necessary ingredients to calculate the SPEI. We calculate the climatic water balance (precipitation minus potential evapotranspiration) at grid cell level for each month. The water balance is then standardized for each grid cell by use of a log-logistic distribution function (applying an unbiased Probability Weighted Moments method). ${ }^{26}$ The SPEI is standardized with zero mean and a standard deviation of one, where negative values indicate a drought. We aggregate the gridded SPEIs to the country level by use of equation (11). To get to the decennial level, we collapse SPEI values to their mean across all months and take only negative values in absolute terms. The resulting SPEI indicator is distributed between 0 and 1.2, with a mean of 0.1 and a standard deviation of 0.2 (compare Figure 2).

\footnotetext{
${ }^{25}$ The SPEI is specifically designed to quantify and monitor droughts according to their intensity and duration (Vicente-Serrano, Beguería and López-Moreno, 2010). It takes the amount of rainfall at given locations as well as the evapotranspiration into account and thus is an advancement of the Standardized Precipitation Index (compare McKee et al., 1993).

${ }^{26}$ Data from the current month and of the respective past nine months are used, giving all months the same weight and taking 1901-2014 as a reference period for obtaining the distribution parameters.
} 

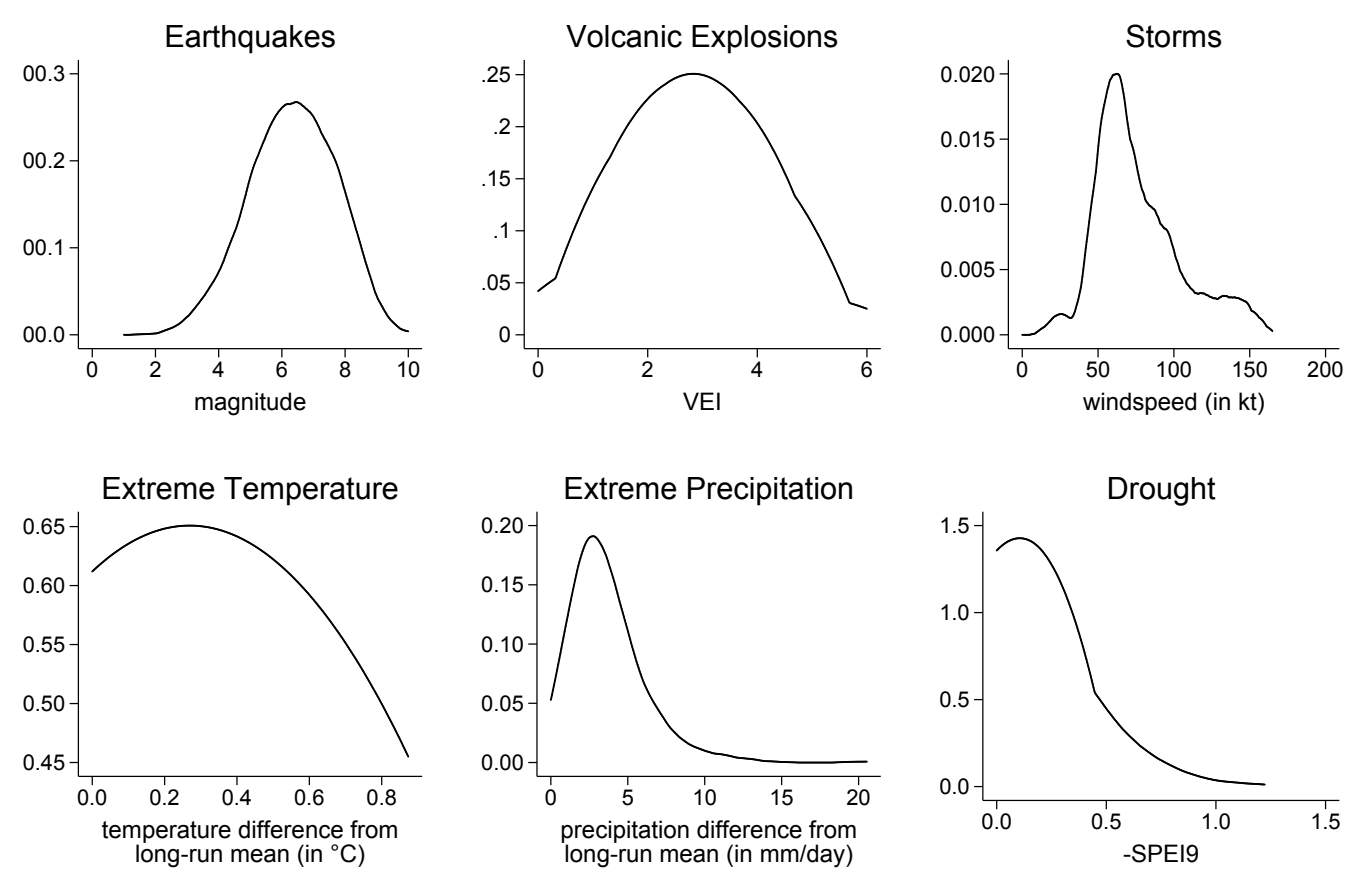

Figure 2: Kernel densities of hazard indicators; zeroes excluded for earthquakes and volcanic explosions

Distribution Across Income Groups. When we compare the above indicators across income groups in Figure 3 in the Appendix, we find that earthquakes are more common among middle-income countries with a mean magnitude of 6.5 , than in high- or lowincome regions. Volcanic explosions also mostly spread across middle-income countries, while there is very little volcanic activity in low-income countries, but quite some activity in high-income groups with a lower standard deviation but a higher mean of 0.5. Storms have the lowest mean density (61.8 knots) in low-income regions with some spread especially at the higher end ( $>100$ knots). Middle-income countries have a higher mean (75.7) but experience more storms in the upper tail, while high-income countries have the highest mean with 85.4 knots. Contrasting this, temperature differences are quite evenly distributed across income groups, as are differences in excess precipitation where middleincome and especially high-income countries experience a long tail. Droughts measured at absolute negative SPEI levels are more prevalent in low-income countries with a mean of 0.3 but less spread than in middle-income regions (standard deviation of 0.2 ).

Hazard Index. We use a combination of four different disaster indices. The simplest one combines all types of hazard intensity measures into an index variable, Hazard Index ${ }_{i, t}$ 
$=$ Quake $_{i, t}+$ Volcano $_{i, t}+$ Storm $_{i, t}+\Delta$ Precipitation $_{i, t}+$ Drought $_{i, t}+\Delta$ Temperature $_{i, t}$, using an equal weights scheme. We also consider an index weighted by the inverse of the standard deviation of each hazard type within a country (compare Felbermayr and Gröschl, 2014). This is guided by the idea of precision weights, such that no one hazard component dominates the movement of the index. Finally, we also take the time dimension into account by weighting each physical intensity with a probability obtained from a normal distribution $f(x)=N(0 ; 1)$ which we fit over 120 months in a decade. ${ }^{27}$ This way, hazard magnitudes are onset weighted at the monthly level, such that events which occur earlier or later within a decade get a smaller weight than events occurring in the middle of a decade when aggregating to the decennial level. The rational for using a bellshaped onset weighting scheme is that the effect of natural hazards that occurred at the beginning of the decade may already have smoothed out before the next census, whereas events occurring at the very end of a decade might not yet show an effect in the census as it takes some time for people to adjust. This approach is adapted to our framework based on an idea by Noy (2009), who studies the impact of disasters on macroeconomic output over a year and linearly adjusts hazards by onset month to account for their occurrence during the observed year. We again take the simple and the inverse standard deviation weighted index combined with onset weighting.

As the impact of a hazard on the economy might depend on the hazard intensity relative to the size of the economy, we follow the literature (i.e., Skidmore and Toya, 2002) and scale all respective disaster variables by land area. This is potentially important, because it alleviates biases resulting from spatial aggregation. Larger countries ceteris paribus have a higher chance of being hit by a hazard of a given magnitude. Moreover, the larger a country is the less likely will a natural hazard at a given location within that country have a statistically significant impact on inward or outward migration. Descriptive statistics on the various hazard indices can be found in Table 5 in the Appendix.

\section{Controls}

Data on population size and GDP per capita stem from the World Bank's World Development Indicators (WDI). Information on civil wars are taken from the Intra-State War Data (v4.1) of the Correlates of War Project. We work with the total number of years involving civil wars within the last 10 years of the reported migration observation. Geographic and cultural linkages - distance, common border, common language, colonial

\footnotetext{
${ }^{27}$ We shift the distribution such that the first and the last month each correspond to $f(-3)$ and $f(3)$ respectively and then re-scale such that $\max [f(x)]=1$, ensuring a maximum probability-weight of 1 .
} 
relation - as well as land area in square kilometers are taken from CEPII's Geographic and Bilateral Distance Database (2011). Information on regional trade agreements comes from the RTA-Gateway of the WTO. ${ }^{28}$ Countries' income groups are defined along 2014 World Bank Gross National Income per capita, using the World Bank Atlas Method.

\section{Results}

This section presents results on the impact of aggregated natural hazards and disaggregated hazard types on medium to long-run migration patterns. We also look into heterogeneity across income groups and present a sensitivity analysis.

\section{A. Baseline Results}

Table 1 reports our baseline results. All regressions include origin and destination country fixed effects, year dummies and respective MR terms. Each column uses a different specification of the physical hazard intensity index as described in Section IV. All hazard indicators are divided by the $\log$ land area to account for size differences of countries. ${ }^{29}$

Across all four specifications, control variables are consistent in sign, overall magnitude, and level of significance. According to column (1), one additional year of civil war at the origin country implies an increase in the bilateral migration rate by $5.7 \%$ over a decade. ${ }^{30}$ Conversely, one additional year of civil war at destination leads to a decline in the bilateral inward migration rate by $23 \%$ over a decade. Presence of a mutual regional trade agreement, a proxy for regional networks, increases the bilateral migration rate by $31.3 \%$. Moreover a ten percent increase in the lagged bilateral migrant stock, a proxy for network effects, implies an increase in the bilateral migration rate by $3.6 \%$. The effect is slightly smaller than the estimated $4 \%$ by Beine and Parsons (2015) and lower than the 6.5\% estimated by Beine, Docquier and Özden (2011), who use different time and country samples. The controls for cultural proximity are also in line with the gravity literature on migration. If bilateral distance increases by ten percent, bilateral migration decreases by $7.5 \%$. The presence of a common official language or common colonial history boost bilateral migration by $65.7 \%$ or $60 \%$ respectively. Wage differences, proxied by the log ratio of destination over origin GDP per capita, show a positive but not statistically significant effect.

\footnotetext{
${ }^{28}$ The RTA gateway is accessible via http://rtais.wto.org/UI/PublicMaintainRTAHome.aspx.

${ }^{29}$ Note that if we do not scale by log land area, we obtain similar results.

$30 \% \Delta$ Mig. Rate $=100 \times\left[e^{\beta}-1\right]$
} 
Table 1: Baseline Results

Dependent Variable: Migration Rate $_{i j, t}$

\begin{tabular}{|c|c|c|c|c|}
\hline & \multicolumn{2}{|c|}{ basic } & \multicolumn{2}{|c|}{ onset weighted } \\
\hline & $\begin{array}{l}\text { simple } \mathrm{sc} \\
(1)\end{array}$ & $\begin{array}{c}\mathrm{d} \text { weighted } \\
(2)\end{array}$ & $\begin{array}{c}\text { simple s } \\
(3)\end{array}$ & $\begin{array}{l}\text { sd weighted } \\
(4)\end{array}$ \\
\hline Hazard Index ${ }_{i, t}$ & $\begin{array}{r}-0.111 \\
(0.09)\end{array}$ & $\begin{array}{l}-0.009^{* * *} \\
(0.00)\end{array}$ & $\begin{array}{c}-0.060 \\
(0.11)\end{array}$ & $\begin{array}{l}0.004^{* * *} \\
(0.00)\end{array}$ \\
\hline Hazard Index $_{j, t}$ & $\begin{array}{c}0.025 \\
(0.11)\end{array}$ & $\begin{array}{r}-0.002 \\
(0.01)\end{array}$ & $\begin{array}{r}0.012 \\
(0.14)\end{array}$ & $\begin{array}{r}-0.013 \\
(0.01)\end{array}$ \\
\hline Controls & & & & \\
\hline $\ln \left(\right.$ GDP p.c. ${ }_{j, t} /$ GDP p.c $\left.\cdot_{i, t}\right)$ & $\begin{array}{c}0.168 \\
(0.23)\end{array}$ & $\begin{array}{c}0.206 \\
(0.23)\end{array}$ & $\begin{array}{c}0.175 \\
(0.23)\end{array}$ & $\begin{array}{c}0.201 \\
(0.23)\end{array}$ \\
\hline Civil $\operatorname{War}_{i, t}$ & $\begin{array}{l}0.055^{* *} \\
(0.03)\end{array}$ & $\begin{array}{l}0.058^{* *} \\
(0.03)\end{array}$ & $\begin{array}{l}0.042^{*} \\
(0.03)\end{array}$ & $\begin{array}{l}0.060^{* *} \\
(0.03)\end{array}$ \\
\hline Civil $\operatorname{War}_{j, t}$ & $\begin{array}{c}-0.261^{* *} \\
(0.11)\end{array}$ & $\begin{array}{c}-0.259^{* *} \\
(0.11)\end{array}$ & $\begin{array}{c}-0.258^{* *} \\
(0.11)\end{array}$ & $\begin{array}{c}-0.258^{* *} \\
(0.11)\end{array}$ \\
\hline $\mathrm{RTA}_{i j, t}$ & $\begin{array}{l}0.272^{* *} \\
(0.12)\end{array}$ & $\begin{array}{l}0.290^{* *} \\
(0.12)\end{array}$ & $\begin{array}{l}0.291^{* *} \\
(0.12)\end{array}$ & $\begin{array}{l}0.294^{* *} \\
(0.12)\end{array}$ \\
\hline $\ln \left(\right.$ Mig. Stock Stj,t-1$\left._{1}+1\right)$ & $\begin{array}{l}0.357^{* * *} \\
(0.03)\end{array}$ & $\begin{array}{l}0.357^{* * *} \\
(0.03)\end{array}$ & $\begin{array}{l}0.358^{* * *} \\
(0.03)\end{array}$ & ** $\begin{array}{l}0.357^{* * *} \\
(0.03)\end{array}$ \\
\hline $\ln \left(\right.$ Distance $\left._{i j}\right)$ & $\begin{array}{l}-0.748^{* * *} \\
(0.08)\end{array}$ & $\begin{array}{l}-0.747^{* * *} \\
(0.08)\end{array}$ & $\begin{array}{c}-0.743^{* * *} \\
(0.08)\end{array}$ & $\begin{array}{c}-0.744^{* * *} \\
(0.08)\end{array}$ \\
\hline Contiguity $_{i j}$ & $\begin{array}{l}0.381^{* *} \\
(0.16)\end{array}$ & $\begin{array}{l}0.380^{* *} \\
(0.16)\end{array}$ & $\begin{array}{l}0.371^{* *} \\
(0.16)\end{array}$ & $\begin{array}{l}0.377^{* *} \\
(0.16)\end{array}$ \\
\hline Common Language $_{i j}$ & $\begin{array}{l}0.505^{* * *} \\
(0.11)\end{array}$ & $\begin{array}{l}0.505^{* * *} \\
(0.11)\end{array}$ & $\begin{array}{l}0.501^{* * *} \\
(0.11)\end{array}$ & $\begin{array}{l}0.508^{* * *} \\
(0.11)\end{array}$ \\
\hline Colony $_{i j}$ & $\begin{array}{l}0.470^{* * *} \\
(0.17)\end{array}$ & $\begin{array}{l}0.467^{* * *} \\
(0.17)\end{array}$ & $\begin{array}{l}0.463^{* * *} \\
(0.17)\end{array}$ & $\begin{array}{l}0.471^{* *} \\
(0.17)\end{array}$ \\
\hline $\begin{array}{l}\text { Log-Likelihood } \\
\text { Observations }\end{array}$ & $\begin{array}{l}-73.980 \\
5,673 \quad 66\end{array}$ & $\begin{array}{l}-74.024 \\
6,673 \quad 66\end{array}$ & $\begin{array}{l}-73.895 \\
673\end{array}$ & $\begin{array}{l}-74.013 \\
6,673\end{array}$ \\
\hline
\end{tabular}

Note: $* * *, * *, *$ denote significance at the $1 \%, 5 \%$ and $10 \%$ level, respectively. Constant, origin, destination and decade fixed effects and MR terms are included but not reported. Natural hazards are scaled by log land area. Robust standard errors reported in parentheses.

The physical intensity hazard index itself shows mixed results across specifications. In column (1), we use the simple physical intensity hazard index, which sums up the physical intensities across all hazard types. Using this indicator, we do not find any statistically significant effects on the bilateral migration rate. In column (2), we use the hazard index weighted by its inverse standard deviation to ensure that the entire index is not driven by variation in only one hazard type. Using this indicator, estimates imply a counter- 
intuitive negative push effect, suggesting that natural hazards at origin have overall led to a decline in the decennial bilateral migration rate. ${ }^{31}$ Timing of the migration decision related to natural hazards might play an important role. Hence, hazards happening at the beginning or towards the end of the decade might not induce migration counting into the decennial census rounds. In columns (3) and (4), we thus take the time dimension into account using a bell-shaped onset-weighting scheme as explained in Section IV. Using the simple onset weighted index still does not yield any statistically significant estimates (column 3). However, if we use onset weighting with the hazard index weighted by inverse standard deviations in column (4), we find a positive and statistically significant push effect, suggesting that natural hazards at origin have overall led to an increase in the bilateral migration rate by $1.68 \%$ (evaluated at the mean). Pull effects are negative but not statistically significant.

The latter finding implies that the timing of migration decisions combined with natural hazard events plays an important role for the identification of migration responses to natural hazards. We thus take column (4) as our default specification. ${ }^{32}$

\section{B. Heterogeneity Across Hazard Types}

As a next step, we simultaneously use intensities of all hazard types. ${ }^{33}$ Again, all physical intensity measures are weighted by log land area, but we obtain very similar results if not done so.

Table 2 shows the coefficients for each physical intensity type. If basic intensity measures are used, we find no statistically significant effects (column (1)). Using onset weighting in column (2) reveals positive push effects of volcanic explosions, suggesting that volcanic events at origin boost the decennial bilateral outward migration rate by $7.9 \%$ (evaluated at the mean). We also obtain a counter-intuitive positive pull effect for earthquakes in destinations, suggesting that people migrate more towards earthquake-prone countries. This result may be driven by middle-income countries, which are more prone to earthquakes (compare Figure (3)) but are also preferred destinations for migrants from low- and other middle-income countries. The reasoning might be that even though earthquakes destroy a lot of capital, the migrants might still be better off due to reconstruction

\footnotetext{
${ }^{31}$ As we show in part $C$ of this section, this effect is driven by high-income origin countries.

${ }^{32}$ While onset weighting can only proxy for the timeliness of adjustment, the exact shape of the actual onset response function requires further research, which lies beyond the scope of this paper.

${ }^{33}$ Using all physical intensities simultaneously might induce multicollinearity into the regression as temperature is also used as a component of potential evapotranspiration in calculating the SPEI. However, if temperature events are omitted from the regression, this does not change our results.
} 
Table 2: Heterogeneity across hazard types

Dependent Variable: Migration Rate $_{i j, t}$

basic onset weighted

(1) (2)

\begin{tabular}{|c|c|c|}
\hline Earthquake $_{i, t}$ & $\begin{array}{c}0.643 \\
(0.48)\end{array}$ & $\begin{array}{r}-0.451 \\
(0.65)\end{array}$ \\
\hline Earthquake $_{j, t}$ & $\begin{array}{r}0.631 \\
(0.77)\end{array}$ & $\begin{array}{l}2.434^{* * *} \\
(0.71)\end{array}$ \\
\hline Volcanic Explosion $_{i, t}$ & $\begin{array}{c}2.144 \\
(1.46)\end{array}$ & $\begin{array}{l}2.452^{* *} \\
(1.24)\end{array}$ \\
\hline Volcanic Explosion $_{j, t}$ & $\begin{array}{l}1.565 \\
(2.06)\end{array}$ & $\begin{array}{c}-1.442 \\
(1.09)\end{array}$ \\
\hline Windspeed $_{i, t}$ & $\begin{array}{r}-0.120 \\
(0.08)\end{array}$ & $\begin{array}{c}-0.044 \\
(0.11)\end{array}$ \\
\hline Windspeed $_{j, t}$ & $\begin{array}{r}0.038 \\
(0.10)\end{array}$ & $\begin{array}{r}0.000 \\
(0.13)\end{array}$ \\
\hline$\Delta$ Precipitation $_{i, t}$ & $\begin{array}{c}0.235 \\
(0.36)\end{array}$ & $\begin{array}{c}0.384 \\
(0.50)\end{array}$ \\
\hline$\Delta$ Precipitation $_{j, t}$ & $\begin{array}{c}-1.058 \\
(1.05)\end{array}$ & $\begin{array}{r}-0.797 \\
(0.76)\end{array}$ \\
\hline$\Delta$ Temperature $_{i, t}$ & $\begin{array}{r}0.120 \\
(3.96)\end{array}$ & $\begin{array}{c}4.373 \\
(7.44)\end{array}$ \\
\hline$\Delta$ Temperature $_{j, t}$ & $\begin{array}{c}-2.434 \\
(6.95)\end{array}$ & $\begin{array}{c}-15.279 \\
(15.70)\end{array}$ \\
\hline Drought $(\mathrm{SPEI}))_{i, t}$ & $\begin{array}{r}-5.300 \\
(3.42)\end{array}$ & $\begin{array}{c}2.076 \\
(6.63)\end{array}$ \\
\hline Drought $(\mathrm{SPEI})_{j, t}$ & $\begin{array}{c}-1.014 \\
(4.94)\end{array}$ & $\begin{array}{r}6.467 \\
(8.97)\end{array}$ \\
\hline $\begin{array}{l}\text { Log-Likelihood } \\
\text { Observations }\end{array}$ & $\begin{array}{l}-73.882 \\
56,673\end{array}$ & $\begin{array}{l}-73.743 \\
66,673\end{array}$ \\
\hline
\end{tabular}

Note: $* * *, * *, *$ denote significance at the $1 \%, 5 \%$ and $10 \%$ level, respectively. Constant, origin, destination and decade fixed effects and MR terms are included but not reported. Natural hazards are scaled by log land area. Robust standard errors reported in parentheses. Controls included as in Table 1.

purposes that might create new jobs (particularly in high- or top-middle income countries with high insurance and investment rates). We cannot pin down the effects of other hazard types. Findings on controls (not shown in the Table) are similar with respect to signs, magnitudes, and levels of significance as in our baseline specification in Table (1). 


\section{Heterogeneity Across Origin Country Groups}

Migration responses of individuals are likely to differ systematically across countries depending on income characteristics. On the one hand, individuals in poor countries may not migrate internationally after a hazardous event, because they are liquidity constrained (see Cattaneo and Peri, 2016). On the other hand, high-income countries usually feature high insurance penetration rates. Thus, individuals from high-income countries may not see the need to migrate if losses from natural hazards are insured. In fact, crop yield destruction can easily be compensated by high-income countries via imports (as they are often financially open), whereas insured damages in built structures and capital assets may even result in a growth-propagating replacement with new, higher quality or more innovative substitutes. This might in turn boost individual's expected earnings and therefore may lead to a decline in migration. In line with this reasoning, we expect not to see a significant migration response to natural hazards by liquidity constrained low-income countries, whereas insured high-income countries may either show no or even a negative effect for hazards at origin. Middle-income countries, where individuals have the financial means to migrate but insurance penetration rates are rather low are thus most likely to migrate internationally in case of natural hazards. Consequently, pooling over all country pairs across all origin income groups might induce aggregation bias into our baseline regression.

Table 3 tests this hypothesis and shows estimates by origin country income groups. ${ }^{34}$ Columns (1) and (2) contain the results for low-income origin countries only. In line with the liquidity-constraint hypothesis, we observe no significant migration effects of our hazard indices. Columns (3) and (4) contain the results for middle-income origins. Evaluated at the mean, the basic result in column (3) suggests a negative and statistically significant pull effect of hazards in potential destinations of $-7.3 \% ;\left(100 \times\left[e^{-0.015 \cdot 5.075}-1\right]\right)$. If we consider the time dimension in column (4), we observe that hazards in the origin increase migration by $1.4 \%$ (evaluated at the mean; $\left(100 \times\left[e^{0.003 \cdot 4.529}-1\right]\right)$ and a negative pull effect at the mean of $-11.5 \% ;\left(100 \times\left[e^{-0.030 \cdot 4.085}-1\right]\right)$. Thus, push and pull effects are largely in line with our priors for the group of middle-income origin countries. Again, timing is important to identify causal effects. Columns (5) and (6) show results for highincome origins. We observe a negative and statistically significant push effect of natural hazards for the basic index in column (5). This finding is in line with the hypothesis that natural hazards might potentially hamper outward migration from high-income countries

\footnotetext{
${ }^{34}$ For descriptives on the distributions of natural hazard types across low-, middle- and high-income countries see Figure 3 in Appendix B.
} 
Table 3: Heterogeneity across origin country income groups

Dependent Variable: Migration Rate $_{i j, t}$

\begin{tabular}{|c|c|c|c|c|c|c|}
\hline & \multicolumn{2}{|c|}{ Low-Income Origins } & \multicolumn{2}{|c|}{ Middle-Income Origins } & \multicolumn{2}{|c|}{ High-Income Origins } \\
\hline & $\begin{array}{c}\text { basic } \\
(1)\end{array}$ & $\begin{array}{l}\text { onset weighted } \\
(2)\end{array}$ & $\begin{array}{c}\text { basic } \\
(3)\end{array}$ & $\begin{array}{l}\text { onset weighted } \\
\text { (4) }\end{array}$ & $\begin{array}{l}\text { basic } \quad 0 \\
(5)\end{array}$ & $\begin{array}{l}\text { onset weighted } \\
(6)\end{array}$ \\
\hline Hazard Index $_{i, t}$ & $\begin{array}{c}-0.011 \\
(0.03)\end{array}$ & $\begin{array}{c}0.039 \\
(0.08)\end{array}$ & $\begin{array}{c}-0.001 \\
(0.02)\end{array}$ & $\begin{array}{l}0.003^{* * *} \\
(0.00)\end{array}$ & $\begin{array}{c}-0.010^{* *} \\
(0.00)\end{array}$ & $\begin{array}{r}-0.037 \\
(0.04)\end{array}$ \\
\hline Hazard Index $_{j, t}$ & $\begin{array}{r}0.005 \\
(0.02)\end{array}$ & $\begin{array}{r}-0.001 \\
(0.01)\end{array}$ & $\begin{array}{c}-0.015^{* *} \\
(0.01)\end{array}$ & $\begin{array}{c}-0.030^{*} \\
(0.02)\end{array}$ & $\begin{array}{r}-0.001 \\
(0.01)\end{array}$ & $\begin{array}{c}-0.015 \\
(0.02)\end{array}$ \\
\hline \multicolumn{7}{|l|}{ Controls } \\
\hline $\ln ($ GDP p.c $\cdot j, t /$ GDP p.c $\cdot i, t)$ & $\begin{array}{l}0.895^{* *} \\
(0.45)\end{array}$ & $\begin{array}{l}0.801^{*} \\
(0.45)\end{array}$ & $\begin{array}{c}0.370 \\
(0.23)\end{array}$ & $\begin{array}{c}0.369 \\
(0.23)\end{array}$ & $\begin{array}{c}-0.322 \\
(0.42)\end{array}$ & $\begin{array}{c}-0.540 \\
(0.41)\end{array}$ \\
\hline Civil $\operatorname{War}_{i, t}$ & $\begin{array}{r}-0.052 \\
(0.04)\end{array}$ & $\begin{array}{c}-0.050 \\
(0.04)\end{array}$ & $\begin{array}{l}0.050^{*} \\
(0.03)\end{array}$ & $\begin{array}{c}0.043 \\
(0.03)\end{array}$ & $\begin{array}{r}0.172 \\
(0.21)\end{array}$ & $\begin{array}{c}0.158 \\
(0.20)\end{array}$ \\
\hline Civil $\operatorname{War}_{j, t}$ & $\begin{array}{c}-0.179^{*} \\
(0.10)\end{array}$ & $\begin{array}{c}-0.177^{*} \\
(0.10)\end{array}$ & $\begin{array}{c}-0.019 \\
(0.04)\end{array}$ & $\begin{array}{r}-0.027 \\
(0.04)\end{array}$ & $\begin{array}{c}-0.477^{* * *} \\
(0.13)\end{array}$ & $\begin{array}{c}-0.484^{* * *} \\
(0.13)\end{array}$ \\
\hline $\mathrm{RTA}_{i j, t}$ & $\begin{array}{l}0.577^{* *} \\
(0.27)\end{array}$ & $\begin{array}{l}0.523^{* *} \\
(0.26)\end{array}$ & $\begin{array}{c}0.173 \\
(0.17)\end{array}$ & $\begin{array}{c}0.213 \\
(0.18)\end{array}$ & $\begin{array}{l}0.705^{* * *} \\
(0.23)\end{array}$ & $\begin{array}{l}0.714^{* * *} \\
(0.23)\end{array}$ \\
\hline $\ln \left(\right.$ Mig. Stock $\left._{i j, t-1}+1\right)$ & $\begin{array}{l}0.386^{* * *} \\
(0.04)\end{array}$ & $\begin{array}{l}0.390^{* * *} \\
(0.04)\end{array}$ & $\begin{array}{l}0.372^{* * *} \\
(0.05)\end{array}$ & $\begin{array}{l}0.371^{* * *} \\
(0.04)\end{array}$ & $\begin{array}{l}0.249^{* * *} \\
(0.05)\end{array}$ & $\begin{array}{l}0.247^{\text {*** }} \\
(0.05)\end{array}$ \\
\hline $\ln \left(\right.$ Distance $\left._{i j}\right)$ & $\begin{array}{c}-0.488^{* * *} \\
(0.12)\end{array}$ & $\begin{array}{c}-0.481^{* * *} \\
(0.12)\end{array}$ & $\begin{array}{c}-0.780^{* * *} \\
(0.10)\end{array}$ & $\begin{array}{c}-0.776^{* * *} \\
(0.10)\end{array}$ & $\begin{array}{c}-0.694^{* * *} \\
(0.11)\end{array}$ & $\begin{array}{c}-0.696^{* * *} \\
(0.11)\end{array}$ \\
\hline Contiguity $_{i j}$ & $\begin{array}{l}1.111^{* * *} \\
(0.22)\end{array}$ & $\begin{array}{l}1.103^{* * *} \\
(0.21)\end{array}$ & $\begin{array}{l}0.521^{\text {*** }} \\
(0.16)\end{array}$ & $\begin{array}{l}0.506^{* * *} \\
(0.16)\end{array}$ & $\begin{array}{c}0.130 \\
(0.36)\end{array}$ & $\begin{array}{r}0.121 \\
(0.35)\end{array}$ \\
\hline Common Language $_{i j}$ & $\begin{array}{l}0.240^{*} \\
(0.14)\end{array}$ & $\begin{array}{c}0.243^{*} \\
(0.15)\end{array}$ & $\begin{array}{l}0.881^{* * *} \\
(0.14)\end{array}$ & $\begin{array}{l}0.876^{* * *} \\
(0.14)\end{array}$ & $\begin{array}{c}0.139 \\
(0.29)\end{array}$ & $\begin{array}{r}0.141 \\
(0.29)\end{array}$ \\
\hline Colony $_{i j}$ & $\begin{array}{r}0.580 \\
(0.39) \\
\end{array}$ & $\begin{array}{c}0.543 \\
(0.38) \\
\end{array}$ & $\begin{array}{r}0.313 \\
(0.21) \\
\end{array}$ & $\begin{array}{l}0.346^{*} \\
(0.21) \\
\end{array}$ & $\begin{array}{l}0.709^{* * *} \\
(0.25)\end{array}$ & $\begin{array}{l}0.723^{* * *} \\
(0.25)\end{array}$ \\
\hline Log-Likelihood & -8.183 & -8.179 & -38.895 & -38.905 & -24.749 & -24.759 \\
\hline Observations & 11,302 & 11,302 & 3,080 & 33,080 & 2,291 & 22,291 \\
\hline
\end{tabular}

Note: $* * *, * * *$ denote significance at the $1 \%, 5 \%$ and $10 \%$ level, respectively. Constant, origin, destination, and decade fixed effects and MR terms are included but not reported. Natural hazard indicator components are weighted with their inverse standard deviation. Natural hazards are scaled by log land area. Robust standard errors reported in parentheses.

due to positive income effects resulting from the replacement of insured losses. Moreover, given the absence of significant push effects for low- and middle-income country groups in columns (1) and (3), we conclude that high income origin countries do drive the negative push effects in column (4) of Table 1. If we weight by onset month in column (6), the effect again vanishes.

The finding that middle-income countries show a positive and statistically significant push effect of natural hazards on bilateral migration is in line with findings on monadic regression by Cattaneo and Peri (2016).

Interestingly, our control variables also show heterogeneity across income groups: While overall wage differences, proxied by relative GDP per capitas, do not play a significant role for the decision to migrate from middle- and high-income countries, they significantly 
drive migration from low-income countries. A ten percent increase in the per capita GDP ratio implies a nearly proportionate increase in the bilateral migration rates from lowincome countries by 8 to 9 percent. Interestingly, armed conflicts in the destination have a very strong deterring effect on potential migrants from high-income countries (who seem to have a strong preference for safety), a smaller but still significantly positive effect for low-income countries (for whom other motives, like escaping poverty, might be more important), and a negative but non-significant effect for middle-income countries. A similar ranking albeit with less pronounced differences in magnitude, obtains for RTAs. Contiguity on the other hand plays the strongest role for low-income countries, with more than three times the effect on the migration rate than for middle-income countries. Adjacency does not seem to play a role for high-income countries. This finding supports the hypothesis that migrants from poorer countries are on average more financially constrained, as moving to neighboring countries implies lower migration cost. Common language is important for middle-income countries, more than doubling the bilateral migration rate, but it does not affect migration for high-income economies. On the other hand, colonial relationships are of major importance for high-income origins, but less so for low- and middle-income economies. Finally, diasporas are equally important for low- and middleincome, but less for high-income countries.

We can conclude that heterogeneity in migration behavior exists across income groups of countries. This leads to aggregation bias if considered jointly and may be responsible for some counterintuitive or non-existent effects (they level out) we have found earlier in this paper.

\section{Sensitivity Analysis}

Migration might only take place if major events occur that drive people out of their home country, while small scale events may not exert an effect on international migration. As a first check, we thus re-construct the hazard intensity index using only the top two standard deviations of our hazard type indicators while setting smaller events to zero. This way, our hazard variable captures major events only. Table 4 column (1) shows that this modification does not lead to statistically significant estimates. ${ }^{35}$

As noted earlier, it might take some time for people to react to hazards and to come up with the decision to migrate, particularly across international borders. As a second check, we thus choose an alternative approach. Instead of applying a bell-shaped onset weighting scheme, we exclude all hazards that took place within two years before each

\footnotetext{
${ }^{35}$ If we use the simple instead of the sd-weighted index, results do not change.
} 
census from our hazard index. The results are shown in Table 4 column (2). Again, the hazard index does not show a significant impact on the bilateral migration rate, but might also not consider timing properly. ${ }^{36}$

The frequency rather than the intensity might matter for the migration decision. We change our hazard variable from physical intensities capturing the strength of hazardous events to a count variable capturing the frequency. For each hazard type we count the number of months within a decade whenever an event beyond a specified threshold ${ }^{37}$ has occurred, and then sum up over all types, creating the inverse weighted index. Columns (3) and (4) in Table 4 show that the hazard frequency does not imply any statistically significant push or pull effects, whether we consider timing or not.

Fourth, we deviate from using FE PPML as the preferred estimation technique and use FE OLS. Estimating OLS causes a loss of 43,418 observations for which the dependent variable is zero. Columns (5) and (6) show that hazards do exert a significant effect on migration. ${ }^{38}$ One peculiarity of the OLS results is that we obtain significant negative effects for RTAs. This finding occurs in OLS due to the lack of country-pair fixed effects causing omitted variable bias (for an overview of the large body of trade gravity literature on this topic, see Head and Mayer, 2014). If bilateral fixed effects are included, RTA effects become insignificant, but in turn the network variable reverses (see Appendix B, Table 8). Since our migration data only covers three decennial waves, the inclusion of bilateral fixed effects is problematic as within-group variation is limited. This problem is aggravated by OLS compared to PPML due to zero migration flows. Hence, we follow Beine and Parsons (2015) by excluding bilateral fixed effects and using direct gravity controls for common country characteristics in all previous and prospective specifications.

Finally, we estimate a Heckman selection model to explore potential heterogeneity in the adaptation mechanism at the extensive versus the intensive margin. In absence of a better instrument, we use the Helpman, Melitz and Rubinstein (2008) common religion measure as a selection variable. Our results suggest that natural hazards in the destination country negatively affect the probability to observe a non-zero migration rate between a

\footnotetext{
${ }^{36}$ Again, using the simple instead of the sd-weighted index does not change this result.

${ }^{37}$ Chosen thresholds are given in Appendix B, Table 6.

${ }^{38}$ Using the simple hazard index instead yields positive push and negative pull effects which are statistically significant. However, this finding is not robust, potentially due to heteroskedastic error terms. A White test proposed by Wooldridge (2003, pp. 268-269) for applications with lengthy regressors yields White's special chi-square test statistic of 109.07 and a p-value of 2.1e-24. The Null hypothesis of homoskedasticity is rejected such that estimated variances under OLS are biased. PPML, beyond solving the problem of zero dependent variables, consistently estimates the gravity equation and is robust to measurement error and different patterns of heteroskedasticity (see Santos Silva and Tenreyro, 2006; Head and Mayer, 2014; Fally, 2015). Estimating FE PPML based on the smaller OLS sample does not yield significant hazard estimators.
} 
country pair (column 7), whereas conditional on the probability that bilateral migration takes place, hazards do not have any statistically significant push or pull effects (column 8). Thus, we conclude that natural hazards rather tend to affect migration at the extensive margin whereas we do not find evidence for an effect at the intensive margin. ${ }^{39}$

\section{Concluding Remarks}

This paper aims to provide an answer to the question on the impact of natural hazards on international migration. To motivate the empirical strategy, we construct a stylized gravity framework of bilateral migration introducing hazards as random shocks. To test the implications empirically, we deploy a full matrix of international migration available for increments of 10 years from 1980 to 2010 and hazard data based on intensity measures of geological and meteorological events only. We run a conditional fixed-effects PPML model to address the issue of zero migration flows and potentially heteroskedastic standard errors. The gravity estimations are augmented by the use of explicit MR terms to control for unobservable time-varying country characteristics.

Our PPML findings show little robust, if at all noisy evidence for push and pull effects of natural hazards on medium to long-run international relocation. We find that hazard intensity in the origin causes bilateral migration to increase by $1.7 \%$ (evaluated at the mean), only if we consider the timing of events with respect to the migration decision using a bell-shaped onset weighting scheme. If timing is neglected or alternative hazard measures are applied, this finding turns out not to be noisy. Decomposing natural hazards by type does not show a clear pattern of events either. Nevertheless, if we distinguish between origin income groups, we find substantial heterogeneity, suggesting that natural hazards have positive push and negative pull effects for middle-income countries. These are neither financially constraint (as low-income countries), nor do they show high insurance penetration rates (as high-income countries). We conclude that examining the effects of natural hazards on migration using a full country sample may lead to aggregation bias.

Finally, we cannot rule out the possibility that the mere aggregation of our ten-year data smooths out a big amount of information, making identification of causal effects problematic. Given our migration data restrictions, our outlined findings must therefore be taken with caution.

\footnotetext{
${ }^{39}$ Note that Heckman results are not directly comparable to PPML, which nest the intensive and extensive effects in one estimate, while Heckman separates them.
} 
Dependent Variable: Migration Rate $_{i j t}(\log$ in OLS)

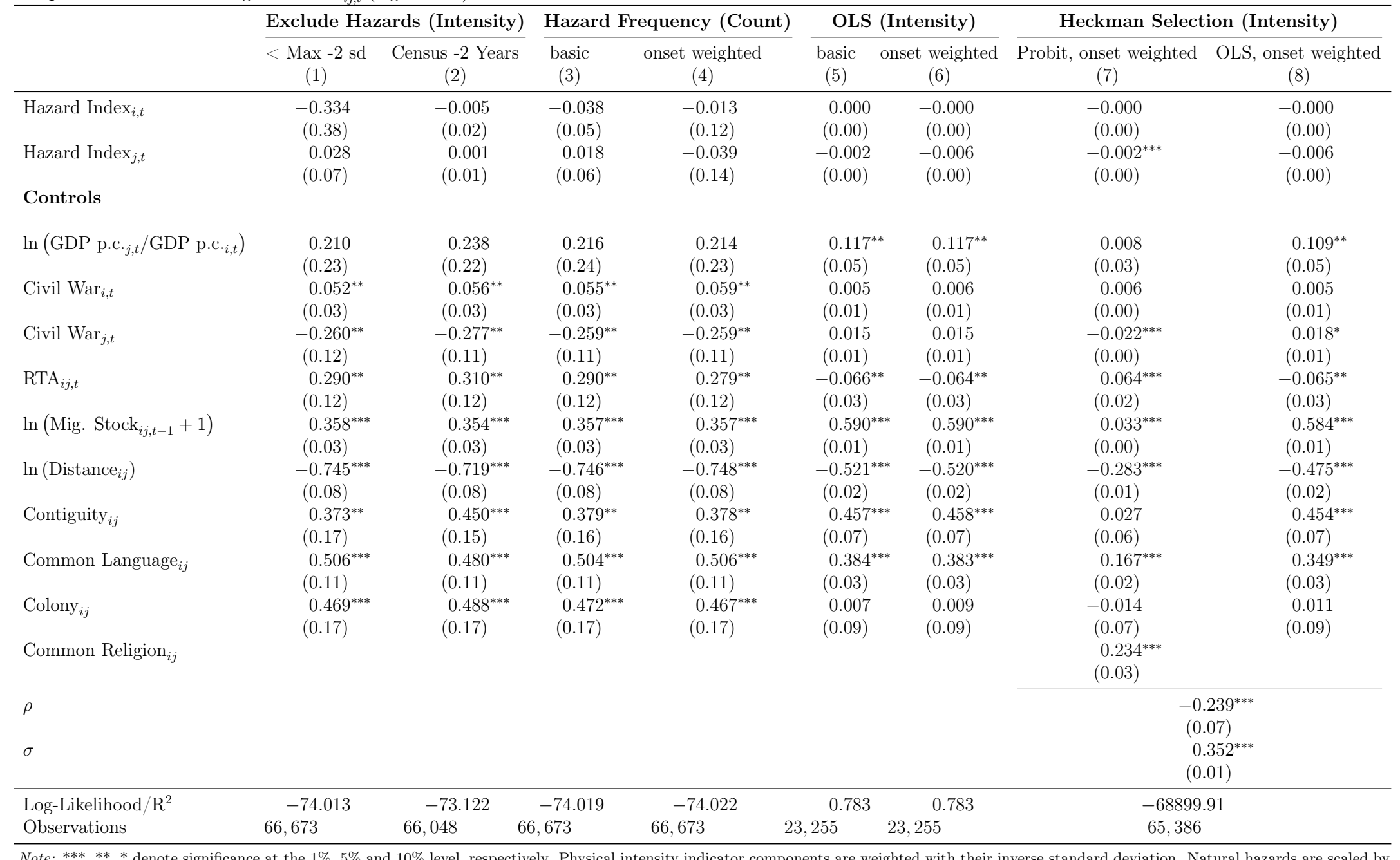




\section{References}

Ambrosetti, Elena, and Enza Roberta Petrillo. 2016. "Environmental Disasters, Migration and Displacement. Insights and Developments from L'Aquila's case." Environmental Science \& Policy, 56: 80-88.

Anderson, J. 2009. "Gravity, Productivity and the Pattern of Production and Trade." NBER Working Paper 14642.

Anderson, J.E. 2011. "The Gravity Model." Annual Review of Economics, 3(1): 133-160.

Backhaus, Andreas, Inmaculada Martinez-Zarzoso, and Chris Muris. 2015. "Do Climate Variations Explain Bilateral Migration? A Gravity Model Analysis." IZA Journal of Migration, 4(1): 1.

Baier, S.L., and J.H. Bergstrand. 2009. "Bonus Vetus OLS: A Simple Method for Approximating International Trade-Cost Effects Using The Gravity Equation." Journal of International Economics, 77(1): 77-85.

Barnett, J., and M. Webber. 2010. "Accommodating Migration to Promote Adaptation to Climate Change." World Bank Policy Research Working Paper 5270.

Barrios, S., L. Bertinelli, and E. Strobl. 2006. "Climatic Change and Rural-Urban Migration: The Case of Sub-Saharan Africa." Journal of Urban Economics, 60(3): 357371.

Beine, M., and C. Parsons. 2015. "Climatic Factors as Determinants of International Migration." Scandinavian Journal of Economics, 117(2): 723-767.

Beine, M., F. Docquier, and Ç. Özden. 2011. "Diasporas." Journal of Development Economics, 95(1): 30-41.

Boeri, T., and H. Brücker. 2005. "Why are Europeans so Tough on Migrants?" Economic Policy, 20(44): 629-703.

Borjas, G. 1987. "Self-Selection and the Earnings of Immigrants." American Economic Review, 77(4): 531-553.

Borjas, G. 1989. "Economic Theory and International Migration." International Migration Review, 23(3): 457-485.

Cattaneo, C., and G. Peri. 2016. "The Migration Response to Increasing Temperatures." Journal of Development Economics, 122: 127-146.

Coniglio, N., and G. Pesce. 2015. "Climate variability and international migration: an empirical analysis." Environment and Development Economics, 20(04): 434-468.

Docquier, F., and E. Lodigiani. 2010. "Skilled Migration and Business Networks." Open Economies Review, 21(4): 565-588. 
Drabo, A., and L. M. Mbaye. 2015. "Natural Disasters, Migration and Education: An Empirical Analysis in Developing Countries." Environment and Development Economics, 20(06): 767-796.

Economist. 2012. "Heated Debate: The Costs of Climate Change Can be Mitigated if Economic Activity Moves in Response." The Economist, Dec 8th 2012.

Fally, Thibault. 2015. "Structural Gravity and Fixed Effects." Journal of International Economics, 97(1): 76-85.

Felbermayr, G., and J. Gröschl. 2014. "Naturally Negative: The Growth Effects of Natural Disasters." Journal of Development Economics, 111: 92-106.

Gibson, J., and D. McKenzie. 2011. "The Microeconomic Determinants of Emigration and Return Migration of the Best and Brightest: Evidence from the Pacific." Journal of Development Economics, 95(1): 18-29.

Grogger, J., and G.H. Hanson. 2011. "Income Maximization and the Selection and Sorting of International Migrants." Journal of Development Economics, 95(1): 42-57.

Head, Keith, and Thierry Mayer. 2014. "Gravity Equations: Workhorse, Toolkit, and Cookbook." Handbook of International Economics, 4: 131-195.

Helpman, Elhanan, Marc Melitz, and Yona Rubinstein. 2008. "Estimating Trade Flows: Trading Partners and Trading Volumes." The Quarterly Journal of Economics, 123(2): 441-487.

INCCCD. 1994. "The Almeria Statement on Desertification and Migration." Intergovernmental Negotiating Committee for a Convention to Combat Desertification, Switzerland.

IPCC. 2012. Managing the Risks of Extreme Events Disasters to Advance Climate Change Adaptation. Intergovernmental Panel on Climate Change.

Kugler, M., and H. Rapoport. 2007. "International Labor and Capital Flows: Complements or Substitutes?" Economics Letters, 94(2): 155-162.

Letouzé, E., M. Purser, F. Rodriguez, and M. Cummins. 2009. "Revisiting the Migration-Development Nexus: A Gravity Model Approach." Human Development Research Papers $2009 / 44$.

Lewer, J.J., and H. Van den Berg. 2008. "A Gravity Model of Immigration." Economics Letters, 99(1): 164-167.

Marchiori, L., and I. Schumacher. 2011. "When Nature Rebels: International Migration, Climate Change, and Inequality." Journal of Population Economics, 24(2): 569600 . 
Mayda, A.M. 2010. "International Migration: A Panel Data Analysis of The Determinants of Bilateral Flows." Journal of Population Economics, 23(4): 1249-1274.

Mbaye, Linguère, and Klaus F Zimmermann. 2015. "Environmental Disasters and Migration." IZA Discussion Paper 9349.

McFadden, D. 1974. Conditional Logit Analysis of Qualitative Choice Behavior, eds. P. Zarembka, Frontiers in Econometrics, 105-142. Academic Press.

McKee, Thomas B, Nolan J Doesken, John Kleist, et al. 1993. "The Relationship of Drought Frequency and Duration to Time Scales." Vol. 17, 179-183, American Meteorological Society Boston, MA.

McLeman, R., and B. Smit. 2006. "Migration as an Adaptation to Climate Change." Climatic Change, 76(1): 31-53.

Mincer, J. 1978. "Family Migration Decisions." Journal of Political Economy, 86(5): 749773.

Munshi, K. 2003. "Networks in the Modern Economy: Mexican Migrants in the US Labor Market." Quarterly Journal of Economics, 118(2): 549-599.

Myers, N., and N. Myers. 2002. "Environmental refugees: a growing phenomenon of the 21st century." Philosophical Transactions of the Royal Society of London. Series B: Biological Sciences, 357(1420): 609-613.

Naudé, W. 2010. "The Determinants of Migration from Sub-Saharan African Countries." Journal of African Economies, 19(3): 330-356.

Noy, I. 2009. "The Macroeconomic Consequences of Disasters." Journal of Development Economics, 88(2): 221-231.

Ortega, F., and G. Peri. 2009. "The Causes and Effects of International Migrations: Evidence from OECD Countries 1980-2005." NBER Working Papers 14833.

Pedersen, P.J., M. Pytlikova, and N. Smith. 2008. "Selection and Network Effects - Migration Flows Into OECD Countries 1990-2000." European Economic Review, 52(7): 1160-1186.

Piguet, E., A. Pécoud, and P. De Guchteneire. 2011. "Migration and Climate Change: An Overview." Refugee Survey Quarterly, 30(3): 1-23.

Rauch, J.E., and V. Trindade. 2002. "Ethnic Chinese Networks in International Trade." Review of Economics and Statistics, 84(1): 116-130.

Reuveny, R., and W.H. Moore. 2009. "Does Environmental Degradation Influence Migration? Emigration to Developed Countries in the Late 1980s and 1990s." Social Science Quarterly, 90(3): 461-479. 
Santos Silva, J., and S. Tenreyro. 2006. "The Log of Gravity." Review of Economics and Statistics, 88(4): 641-658.

Sjaastad, L. 1962. "The Costs and Returns of Human Migration." Journal of Political Economy, 70(5): 80-93.

Skidmore, M., and H. Toya. 2002. "Do Natural Disasters Promote Long-Run Growth?" Economic Inquiry, 40(4): 664-687.

Stark, O. 1991. The Migration of Labor. Blackwell Oxford.

Stern, N.H. 2006. Stern Review on the Economics of Climate Change. Cambridge University Press.

Tacoli, C. 2009. "Crisis or Adaptation? Migration and Climate Change in a Context of High Mobility." Environment and Urbanization, 21(2): 513-525.

Vicente-Serrano, Sergio M, Santiago Beguería, and Juan I López-Moreno. 2010. "A Multiscalar Drought Index Sensitive to Global Warming: The Standardized Precipitation Evapotranspiration Index." Journal of Climate, 23(7): 1696-1718.

Wooldridge, Jeffrey M. 2003. Introductory Econometrics: A Modern Approach, 2 ed. Thomson South-Western.

World Bank. 2012. "Turn Down the Heat: Why a 4 Degree Celsius Warmer World Must be Avoided." International Bank for Reconstruction and Development / The World Bank. 


\section{A. Appendix}

Details on the Taylor series expansion to obtain tractable MR terms estimated in the empirical specifications. From the theoretical derivations in section II, MR terms are given by

$$
\begin{gathered}
\tilde{\Gamma}_{i, t}=\left[\sum_{j} \delta_{j, t}\left(\frac{\theta_{i j, t}}{\tilde{\Gamma}_{j, t}}\right)^{1-\sigma}\right]^{\frac{1}{1-\sigma}}, \\
\tilde{\Gamma}_{j, t}=\left[\sum_{i} \delta_{i, t}\left(\frac{\theta_{i j, t}}{\tilde{\Gamma}_{i, t}}\right)^{1-\sigma}\right]^{\frac{1}{1-\sigma}},
\end{gathered}
$$

where $\delta$ is $N_{i, t} / N_{t}$ or $N_{j, t} / N_{t}$, respectively.

The first order Taylor series expansion of any function $f\left(x_{i}\right)$, centered at $x$, is given by $f\left(x_{i}\right)=f(x)+\left[f^{\prime}(x)\right]\left(x_{i}-x\right)$. We follow Baier and Bergstrand (2009) and center around symmetric migration frictions $\theta_{i j, t}=\theta$. We start by dividing both sides of equation (12) by a constant $\theta^{1 / 2}$ :

$$
\begin{aligned}
\tilde{\Gamma}_{i, t} / \theta^{1 / 2} & =\left[\sum_{j} \delta_{j, t}\left(\theta_{i j, t} / \theta^{1 / 2}\right)^{1-\sigma} / \tilde{\Gamma}_{j, t}^{1-\sigma}\right]^{\frac{1}{1-\sigma}} \\
= & {\left[\sum_{j} \delta_{j, t}\left(\theta_{i j, t} / \theta\right)^{1-\sigma} /\left(\tilde{\Gamma}_{j, t} / \theta^{1 / 2}\right)^{1-\sigma}\right]^{\frac{1}{1-\sigma}} }
\end{aligned}
$$

We define $\hat{\Gamma}_{i, t}=\tilde{\Gamma}_{i, t} / \theta^{1 / 2}, \hat{\theta}_{i j, t}=\theta_{i j, t} / \theta$, and $\hat{\Gamma}_{j, t}=\tilde{\Gamma}_{j, t} / \theta^{1 / 2}$. Substituting these in the previous equation, we obtain

$$
\hat{\Gamma}_{i, t}=\left[\sum_{j} \delta_{j, t}\left(\hat{\theta}_{i j, t} / \hat{\Gamma}_{j, t}\right)^{1-\sigma}\right]^{\frac{1}{1-\sigma}} .
$$

It will later be useful to rewrite equation (15) as

$$
e^{(1-\sigma) \ln \hat{\Gamma}_{i, t}}=\sum_{j} e^{\ln \delta_{j, t}} e^{(\sigma-1) \ln \hat{\Gamma}_{j, t}} e^{(1-\sigma) \ln \hat{\theta}_{i j, t}},
$$

where $e$ is the natural logarithm operator. In a world with symmetric migration costs $\theta_{i j, t}=\theta$, connoting $\hat{\theta}_{i j, t}=1$, the latter implies

$$
\hat{\Gamma}_{i, t}^{1-\sigma}=\sum_{j} \delta_{j, t} \hat{\Gamma}_{j, t}^{\sigma-1}
$$


multiplying both sides by $\hat{\Gamma}_{i, t}^{\sigma-1}$ yields

$$
1=\sum_{j} \delta_{j, t}\left(\hat{\Gamma}_{i, t} \hat{\Gamma}_{j, t}\right)^{\sigma-1}
$$

As noted in Feenstra (2004, p.158, footnote 11), the solution to this equation is $\hat{\Gamma}_{i, t}=$ $\hat{\Gamma}_{j, t}=1$. For this reason, under symmetric migration costs $\hat{\theta}_{i j, t}=\hat{\Gamma}_{i, t}=\hat{\Gamma}_{j, t}=1$ and $\Gamma_{i, t}=\Gamma_{j, t}=\theta^{1 / 2}$.

A first-order log-linear Taylor series expansion of $\hat{\Gamma}_{i, t}$ from equation (16), analogue for $\hat{\Gamma}_{j, t}$, centered at $\hat{\theta}=\hat{\Gamma}_{i, t}=\hat{\Gamma}_{j, t}=1$ yields

$$
\ln \tilde{\Gamma}_{i, t}=-\sum_{j} \delta_{j, t} \ln \tilde{\Gamma}_{j, t}+\sum_{j} \delta_{j, t} \ln \theta_{i j, t}
$$

and

$$
\ln \tilde{\Gamma}_{j, t}=-\sum_{i} \delta_{i, t} \ln \tilde{\Gamma}_{i, t}+\sum_{i} \delta_{i, t} \ln \theta_{i j, t}
$$

Using $d\left[e^{(1-\sigma) \ln \hat{x}}\right] / d[\ln \hat{x}]=(1-\sigma) e^{(1-\sigma) \ln \hat{x}}$, some mathematical manipulation and assuming symmetry of migration costs, a solution to the above equations is

$$
\ln \tilde{\Gamma}_{i, t}=\left[\sum_{j} \delta_{j, t} \ln \theta_{i j, t}-\frac{1}{2} \sum_{k} \sum_{m} \delta_{k, t} \delta_{m, t} \ln \theta_{k m, t}\right]
$$

and

$$
\ln \tilde{\Gamma}_{j, t}=\left[\sum_{i} \delta_{i, t} \ln \theta_{i j, t}-\frac{1}{2} \sum_{k} \sum_{m} \delta_{k, t} \delta_{m, t} \ln \theta_{k m, t}\right],
$$

where multilateral resistances are normalized by (the square root of) population weighted average migration frictions (the combined shock-cost measure). 
In the empirical specification MR terms are calculated as

$$
\begin{aligned}
\operatorname{MRDIST}_{i j, t}= & {\left[\left(\sum_{k=1}^{C} \delta_{k, t}\left(\ln \operatorname{Dist}_{i k}+\Phi_{k, t}-\Phi_{i, t}\right)\right)\right.} \\
& +\left(\sum_{m=1}^{C} \delta_{m, t}\left(\ln \operatorname{Dist}_{m j}+\Phi_{j, t}-\Phi_{m, t}\right)\right) \\
& \left.-\left(\sum_{k=1}^{C} \sum_{m=1}^{C} \delta_{k, t} \delta_{m, t}\left(\ln \operatorname{Dist}_{k m}+\Phi_{m, t}-\Phi_{k, t}\right)\right)\right], \\
\operatorname{MRADJ}_{i j, t}= & {\left[\left(\sum_{k=1}^{C} \delta_{k, t}\left(\operatorname{Adj}_{i k}+\Phi_{k, t}-\Phi_{i, t}\right)\right)\right.} \\
& +\left(\sum_{m=1}^{C} \delta_{m, t}\left(\operatorname{Adj}_{m j}+\Phi_{j, t}-\Phi_{m, t}\right)\right) \\
& \left.-\left(\sum_{k=1}^{C} \sum_{m=1}^{C} \delta_{k, t} \delta_{m, t}\left(\operatorname{Adj}_{k m}+\Phi_{m, t}-\Phi_{k, t}\right)\right)\right],
\end{aligned}
$$

where $\delta$ denotes a states' share of population over 'total' world population, $\mathrm{N}_{k, t} / \mathrm{N}_{t}$ and $\mathrm{N}_{m, t} / \mathrm{N}_{t}$.

MR terms for RTA, Colony and Common Language are calculated analogously. 


\section{B. Appendix}
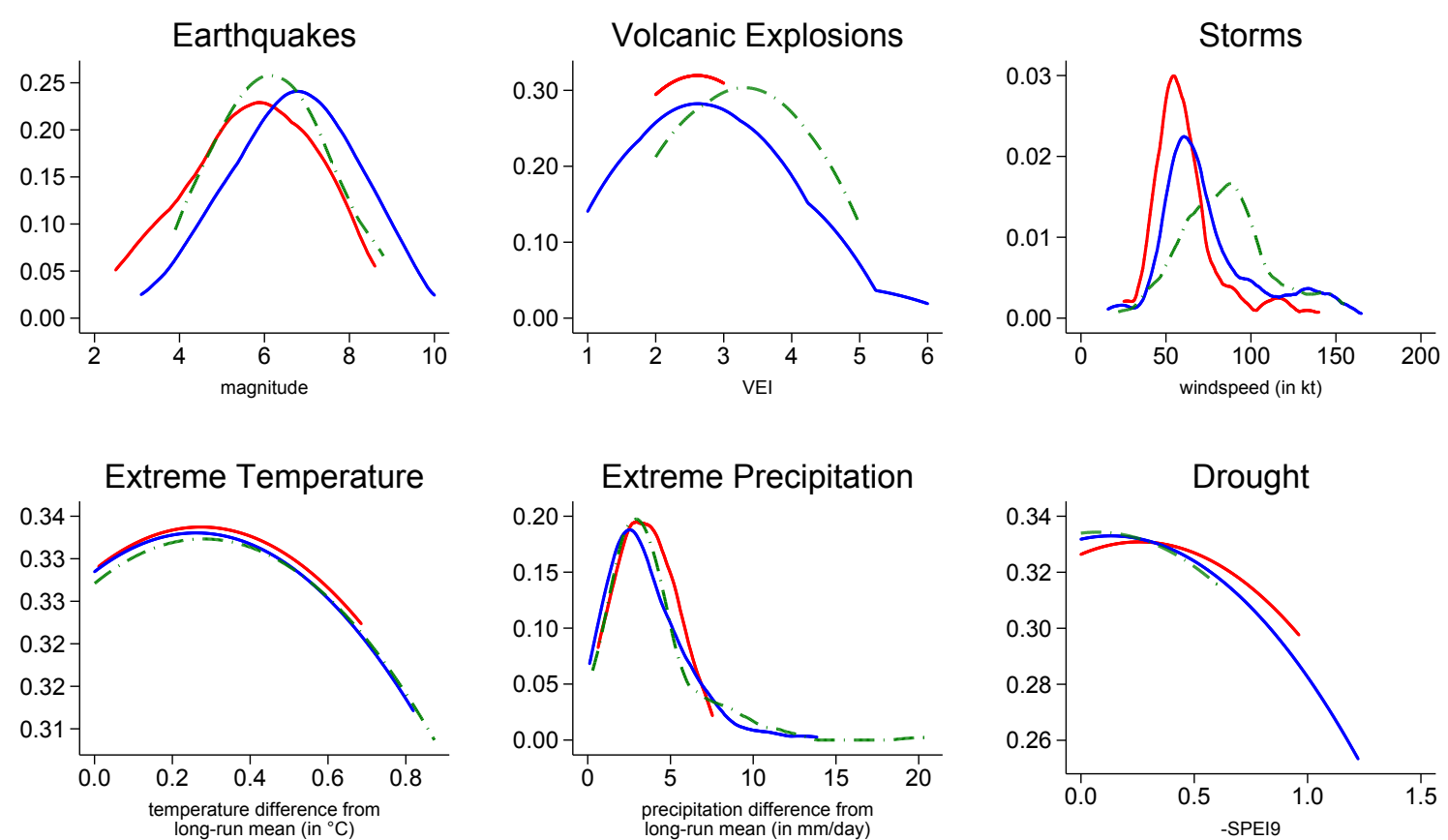

Low Income

_ Middle Income $\quad$ - $\quad$ - ' High Income

Figure 3: Kernel densities of hazard indicators by country income groups at decennial level; zeroes excluded for earthquakes and volcanic explosions 
Table 5: Summary Statistics, PPML, Full Sample

\begin{tabular}{|c|c|c|c|c|}
\hline & mean & sd & $\min$ & $\max$ \\
\hline Migration Rate $_{i j, t}$ & 0.0002 & 0.003 & 0.000 & 0. \\
\hline \multicolumn{5}{|l|}{ Aggregate Hazard Indices } \\
\hline Hazard Index $_{i, t}$ & 7.370 & 2.842 & 1.616 & 19.5 \\
\hline Hazard Index ${ }_{j, t}$ & 7.421 & 2.855 & 1.616 & 19. \\
\hline Hazard Index $_{i, t}$, onset weighted & 5.777 & 2.247 & 0.767 & 15.5 \\
\hline Hazard Index $j, t$, onset weighted & 5.813 & 2.256 & 0.767 & 15.5 \\
\hline Hazard Index $_{i, t}$, sd weighted & 5.096 & 21.526 & 0 & 322.0 \\
\hline Hazard Index $_{j, t}$, sd weighted & 5.102 & 22.082 & 0 & 322. \\
\hline Hazard Index $i, t$, onset weighted, sd weighted & 4.156 & 14.855 & 0 & 533.0 \\
\hline Hazard Index $_{j, t}$, onset weighted, sd weighted & 4.196 & 15.113 & 0 & 533.0 \\
\hline Hazard Index $i, t$, major & 1.873 & 4.061 & 0 & 17.7 \\
\hline Hazard Index $_{j, t}$, major & 1.896 & 4.101 & 0 & 17.7 \\
\hline Hazard Index $i, t$, census $-2 y r s$ & 7.130 & 2.749 & 1.621 & 19.3 \\
\hline Hazard Index ${ }_{j, t}$, census $-2 y r s$ & 7.182 & 2.764 & 1.621 & 19.3 \\
\hline Hazard Counts $_{i, t}$ & 14.137 & 6.144 & 2.565 & 33.5 \\
\hline Hazard Counts $_{j, t}$ & 14.152 & 6.199 & 2.565 & 33.5 \\
\hline Hazard Counts $_{i, t}$, onset & 5.880 & 2.528 & 0.710 & 13.8 \\
\hline Hazard Counts $_{j, t}$, onset & 5.886 & 2.550 & 0.710 & 13.8 \\
\hline
\end{tabular}

\section{Hazard Types (basic)}

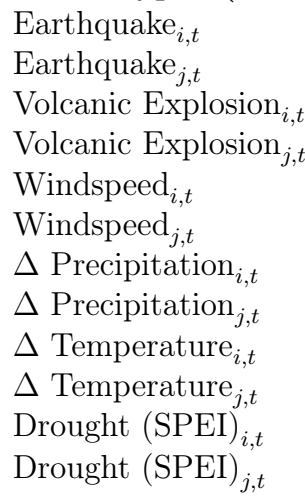

$\begin{array}{rrlr}0.511 & 0.158 & 0 & 0.947 \\ 0.510 & 0.160 & 0 & 0.947 \\ 0.042 & 0.093 & 0 & 0.476 \\ 0.043 & 0.093 & 0 & 0.476 \\ 6.455 & 2.641 & 1.133 & 17.709 \\ 6.502 & 2.649 & 1.133 & 17.709 \\ 0.329 & 0.278 & 0.008 & 2.936 \\ 0.333 & 0.282 & 0.008 & 2.936 \\ 0.023 & 0.018 & 2.1 e-05 & 0.115 \\ 0.023 & 0.018 & 2.1 e-05 & 0.115 \\ 0.012 & 0.018 & 0 & 0.127 \\ 0.012 & 0.018 & 0 & 0.127\end{array}$

\section{Hazard Types (onset weighted)}

Earthquake $_{i, t}$

Earthquake $_{j, t}$

Volcanic Explosion Ex $_{i, t}$

Volcanic Explosion Ex $_{j, t}$

Windspeed $_{i, t}$

Windspeed $_{j, t}$

$\Delta$ Precipitation $_{i, t}$

$\Delta$ Precipitation $_{j, t}$

$\Delta$ Temperature $_{i, t}$

$\Delta$ Temperature $_{j, t}$

Drought $(\mathrm{SPEI})_{i, t}$

Drought $(\mathrm{SPEI})_{j, t}$

$\begin{array}{lllr}0.418 & 0.155 & 0 & 0.792 \\ 0.418 & 0.155 & 0 & 0.792 \\ 0.031 & 0.072 & 0 & 0.311 \\ 0.0315 & 0.073 & 0 & 0.311 \\ 5.094 & 2.127 & 0.119 & 13.899 \\ 5.127 & 2.135 & 0.119 & 13.899 \\ 0.218 & 0.198 & 0.006 & 1.404 \\ 0.221 & 0.199 & 0.006 & 1.404 \\ 0.011 & 0.008 & 9.9 e-05 & 0.048 \\ 0.011 & 0.008 & 9.9 e-05 & 0.048 \\ 0.005 & 0.009 & 0 & 0.072 \\ 0.005 & 0.009 & 0 & 0.072\end{array}$

\section{Controls}

$$
\begin{aligned}
& \ln \left(\text { GDP p.c }_{j, t} /\right. \text { GDP p.c. } \\
& \text { Civil } \left._{i, t}\right) \\
& {\text { Civil } \operatorname{War}_{j, t}} \\
& \text { RTA }_{i j, t} \\
& \ln \left(\text { Mig. }_{\text {Stock }_{i j, t-1}}+1\right) \\
& \ln \left(\text { Distance }_{i j}\right) \\
& \text { Contiguity }_{i j} \\
& \text { Common Language }_{i j} \\
& \text { Colony }_{i j}
\end{aligned}
$$

\begin{tabular}{llll}
0.028 & 2.187 & -6.149 & 6.149 \\
0.729 & 1.947 & 0 & 10 \\
0.721 & 1.948 & 0 & 10 \\
0.169 & 0.375 & 0 & 1 \\
2.608 & 3.084 & 0 & 16.053 \\
8.718 & 0.774 & 2.349 & 9.894 \\
0.021 & 0.143 & 0 & 1 \\
0.147 & 0.354 & 0 & 1 \\
0.013 & 0.114 & 0 & 1 \\
\hline
\end{tabular}

Note: 66,673 Observations, all hazard variables are land area weighted. 
Table 6: Standard Thresholds for Hazard Count Variables

\begin{tabular}{|c|c|c|c|}
\hline Count Indicator & Intensity Measure & Bound & Minimum Event Type \\
\hline Earthquakes & maximum magnitude & $\geq 4$ & $\begin{array}{l}\text { felt shaking of the earth with light } \\
\text { damage caused to buildings and } \\
\text { structures }\end{array}$ \\
\hline Storms & maximum sustained wind speed & $\geq 64$ knots & $\begin{array}{l}\text { some damage to buildings and trees, } \\
\text { extensive damage to to power lines } \\
\text { and poles } \\
\text { (Cat. } 1 \text { on Saffir-Simpson Hurricane } \\
\text { Scale) }\end{array}$ \\
\hline Volcanoes & $\begin{array}{l}\text { maximum Volcanic Explosivity Index } \\
\text { (VEI) }\end{array}$ & $\geq 1$ & $\begin{array}{l}\text { light eruption with ejecta volume }> \\
10,000 \mathrm{~m}^{3}\end{array}$ \\
\hline Extreme Precipitation & $\begin{array}{l}\text { positive difference of monthly mean } \\
\text { precipitation from monthly long-run } \\
\text { mean }\end{array}$ & $\geq 1.5 \mathrm{~mm} /$ day & excess-rain anomaly \\
\hline Extreme Temperatures & $\begin{array}{l}\text { absolute difference of monthly mean } \\
\text { temperature from monthly long-run } \\
\text { mean }\end{array}$ & $\geq 1.5^{\circ} \mathrm{C}$ & temperature anomaly \\
\hline Droughts & $\begin{array}{l}\text { mean Standardized Precipitation } \\
\text { Evapotranspiration Index (SPEI) }\end{array}$ & $\leq 0$ & $\begin{array}{l}\text { mild drought (Vicente-Serrano, } \\
\text { Beguería and López-Moreno, 2010) }\end{array}$ \\
\hline
\end{tabular}


Table 7: Countries in PPML Specification

\begin{tabular}{|c|c|c|c|c|c|}
\hline & \multicolumn{2}{|c|}{ Case numbers } & & \multicolumn{2}{|c|}{ Case numbers } \\
\hline & Origin & Destination & & Origin & Destination \\
\hline Afghanistan & 151 & 0 & Kuwait & 307 & 318 \\
\hline Albania & 439 & 450 & Kyrgyzstan & 439 & 450 \\
\hline Algeria & 440 & 289 & Lao People's Democratic Republic & 439 & 450 \\
\hline Angola & 439 & 450 & Latvia & 307 & 318 \\
\hline Argentina & 439 & 450 & Lebanon & 440 & 289 \\
\hline Armenia & 307 & 318 & Lesotho & 439 & 450 \\
\hline Australia & 439 & 450 & Liberia & 439 & 450 \\
\hline Austria & 439 & 450 & Libya & 307 & 318 \\
\hline Azerbaijan & 307 & 318 & Lithuania & 307 & 318 \\
\hline Bahamas & 439 & 450 & Luxembourg & 439 & 450 \\
\hline Bahrain & 439 & 450 & Madagascar & 439 & 450 \\
\hline Bangladesh & 439 & 450 & Malawi & 439 & 450 \\
\hline Belarus & 307 & 318 & Malaysia & 439 & 450 \\
\hline Belgium & 439 & 450 & Mali & 439 & 450 \\
\hline Belize & 439 & 450 & Mauritania & 439 & 450 \\
\hline Benin & 439 & 450 & Mauritius & 439 & 450 \\
\hline Bhutan & 150 & 161 & Mexico & 439 & 450 \\
\hline Bolivia (Plurinational State of) & 439 & 450 & Mongolia & 439 & 450 \\
\hline Bosnia and Herzegovina & 307 & 318 & Morocco & 440 & 289 \\
\hline Botswana & 440 & 289 & Mozambique & 439 & 450 \\
\hline Brazil & 439 & 450 & Namibia & 439 & 450 \\
\hline Brunei Darussalam & 439 & 450 & Nepal & 439 & 450 \\
\hline Bulgaria & 439 & 450 & Netherlands & 439 & 450 \\
\hline Burkina Faso & 439 & 450 & New Zealand & 439 & 450 \\
\hline Burundi & 439 & 450 & Nicaragua & 439 & 450 \\
\hline Cambodia & 307 & 318 & Niger & 439 & 450 \\
\hline Cameroon & 439 & 450 & Nigeria & 439 & 450 \\
\hline Canada & 439 & 450 & Norway & 439 & 450 \\
\hline Central African Republic & 439 & 450 & Oman & 439 & 450 \\
\hline Chad & 439 & 450 & Pakistan & 440 & 289 \\
\hline Chile & 439 & 450 & Panama & 439 & 450 \\
\hline China & 440 & 289 & Papua New Guinea & 439 & 450 \\
\hline China, Hong Kong Special Administrati.. & 439 & 450 & Paraguay & 439 & 450 \\
\hline Colombia & 439 & 450 & Peru & 439 & 450 \\
\hline Congo & 439 & 450 & Philippines & 439 & 450 \\
\hline Costa Rica & 439 & 450 & Poland & 307 & 318 \\
\hline Croatia & 307 & 318 & Portugal & 439 & 450 \\
\hline Cuba & 439 & 450 & Puerto Rico & 439 & 450 \\
\hline Cyprus & 439 & 450 & Qatar & 150 & 161 \\
\hline Czech Republic & 307 & 318 & Republic of Korea & 439 & 450 \\
\hline Côte d'Ivoire & 439 & 450 & Republic of Moldova & 439 & 450 \\
\hline Democratic Republic of the Congo & 440 & 289 & Romania & 307 & 318 \\
\hline Denmark & 439 & 450 & Russian Federation & 439 & 450 \\
\hline Djibouti & 307 & 318 & Rwanda & 439 & 450 \\
\hline Dominican Republic & 439 & 450 & Saudi Arabia & 439 & 450 \\
\hline Ecuador & 439 & 450 & Senegal & 439 & 450 \\
\hline Egypt & 439 & 450 & Sierra Leone & 439 & 450 \\
\hline El Salvador & 439 & 450 & Singapore & 439 & 450 \\
\hline Equatorial Guinea & 307 & 318 & Slovakia & 307 & 318 \\
\hline Eritrea & 308 & 157 & Slovenia & 307 & 318 \\
\hline Estonia & 307 & 318 & Solomon Islands & 307 & 318 \\
\hline Ethiopia & 439 & 450 & South Africa & 439 & 450 \\
\hline Fiji & 439 & 450 & Spain & 439 & 450 \\
\hline Finland & 439 & 450 & Sri Lanka & 439 & 450 \\
\hline France & 439 & 450 & Sudan & 439 & 450 \\
\hline Gabon & 439 & 450 & Suriname & 439 & 450 \\
\hline Gambia & 439 & 450 & Swaziland & 439 & 450 \\
\hline Georgia & 439 & 450 & Sweden & 439 & 450 \\
\hline Germany & 439 & 450 & Switzerland & 439 & 450 \\
\hline Ghana & 440 & 289 & Tajikistan & 439 & 450 \\
\hline Greece & 439 & 450 & Thailand & 439 & 450 \\
\hline Guatemala & 439 & 450 & The former Yugoslav Republic of Maced.. & 307 & 318 \\
\hline Guinea & 439 & 450 & $\begin{array}{r}\text { Togo } \\
\end{array}$ & 439 & 450 \\
\hline Guinea-Bissau & 439 & 450 & Trinidad and Tobago & 439 & 450 \\
\hline Guyana & 439 & 450 & Tunisia & 439 & 450 \\
\hline Haiti & 307 & 318 & Turkey & 439 & 450 \\
\hline Honduras & 439 & 450 & Turkmenistan & 439 & 450 \\
\hline Hungary & 307 & 318 & Uganda & 439 & 450 \\
\hline Iceland & 439 & 450 & Ukraine & 439 & 450 \\
\hline India & 439 & 450 & United Arab Emirates & 150 & 161 \\
\hline Indonesia & 439 & 450 & United Kingdom of Great Britain and N.. & 439 & 450 \\
\hline Iran (Islamic Republic of) & 439 & 450 & United Republic of Tanzania & 439 & 450 \\
\hline Iraq & 439 & 450 & United States of America & 439 & 450 \\
\hline Ireland & 439 & 450 & Uruguay & 439 & 450 \\
\hline Israel & 439 & 450 & Uzbekistan & 439 & 450 \\
\hline Italy & 439 & 450 & Vanuatu & 439 & 450 \\
\hline Jamaica & 439 & 450 & Venezuela (Bolivarian Republic of) & 439 & 450 \\
\hline Japan & 439 & 450 & Viet Nam & 440 & 289 \\
\hline Jordan & 439 & 450 & Yemen & 307 & 318 \\
\hline Kazakhstan & 307 & 318 & Zambia & 439 & 450 \\
\hline Kenya & 439 & 450 & Zimbabwe & 439 & 450 \\
\hline
\end{tabular}

Note: Case numbers extracted from post-estimation sample tabulation. 
Table 8: OLS, Full Sample, 1980-2010, Bilateral Fixed Effects

Dependent Variable: Migration Rate $_{i j, t}$

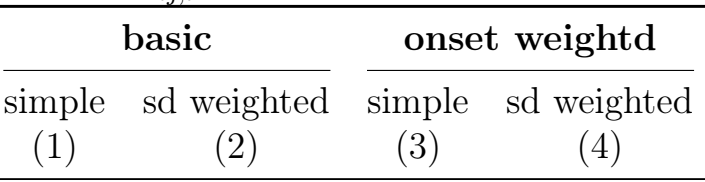

\begin{tabular}{|c|c|c|c|c|}
\hline Hazard Index $_{i, t}$ & $\begin{array}{l}0.059 * * \\
(0.03)\end{array}$ & $\begin{array}{c}-0.062 \\
(0.08)\end{array}$ & $\begin{array}{l}0.070 * \\
(0.04)\end{array}$ & $\begin{array}{c}0.106 \\
(0.08)\end{array}$ \\
\hline Hazard Index $_{j, t}$ & $\begin{array}{c}-0.174^{* * *} \\
(0.03)\end{array}$ & $\begin{array}{c}-0.196^{* *} \\
(0.08)\end{array}$ & $\begin{array}{c}-0.070^{*} \\
(0.04)\end{array}$ & $\begin{array}{l}0.269^{* * *} \\
(0.09)\end{array}$ \\
\hline \multicolumn{5}{|l|}{ Controls } \\
\hline $\ln \left(\right.$ GDP p.c. ${ }_{j, t} /$ GDP p.c. $\left.{ }_{i, t}\right)$ & $\begin{array}{l}0.371^{* * *} \\
(0.06)\end{array}$ & $\begin{array}{l}0.398^{* * *} \\
(0.06)\end{array}$ & $\begin{array}{l}0.419^{* * *} \\
(0.06)\end{array}$ & $\begin{array}{l}0.415^{* * *} \\
(0.06)\end{array}$ \\
\hline Civil $\operatorname{War}_{i, t}$ & $\begin{array}{c}0.011 \\
(0.01)\end{array}$ & $\begin{array}{c}0.010 \\
(0.01)\end{array}$ & $\begin{array}{c}0.008 \\
(0.01)\end{array}$ & $\begin{array}{c}0.012 \\
(0.01)\end{array}$ \\
\hline Civil $\operatorname{War}_{j, t}$ & $\begin{array}{l}0.027^{* * *} \\
(0.01)\end{array}$ & $\begin{array}{l}0.026^{* * *} \\
(0.01)\end{array}$ & $\begin{array}{l}0.032^{* * *} \\
(0.01)\end{array}$ & $\begin{array}{l}0.033^{* * *} \\
(0.01)\end{array}$ \\
\hline $\mathrm{RTA}_{i j, t}$ & $\begin{array}{c}-0.052 \\
(0.06)\end{array}$ & $\begin{array}{c}-0.049 \\
(0.06)\end{array}$ & $\begin{array}{c}-0.050 \\
(0.06)\end{array}$ & $\begin{array}{c}-0.043 \\
(0.06)\end{array}$ \\
\hline $\ln \left(\right.$ Mig. Stock Stj,t-1 $\left._{i}+1\right)$ & $\begin{array}{c}-0.114^{* * *} \\
(0.01)\end{array}$ & $\begin{array}{c}-0.121^{* * *} \\
(0.01)\end{array}$ & $\begin{array}{c}-0.122^{* * *} \\
(0.01)\end{array}$ & $\begin{array}{c}-0.125^{* * *} \\
(0.01)\end{array}$ \\
\hline $\mathrm{R}^{2}$ (within) & 0.079 & 0.071 & \multirow{2}{*}{\multicolumn{2}{|c|}{$\begin{array}{ll}0.071 & 0.071 \\
55 & 23,255\end{array}$}} \\
\hline Observations & 255 & 255 & & \\
\hline
\end{tabular}

Note: $* * *, * *, *$ denote significance at the $1 \%, 5 \%$ and $10 \%$ level, respectively. Constant, bilateral and decade fixed effects, and MR terms are included but not reported. Robust standard errors reported in parentheses. 